Article

\title{
Experimental Analysis of River Evolution with Riparian Vegetation
}

\author{
Shuqing Yang ${ }^{1}$, Yuchuan Bai ${ }^{1,2, *}$ and Haijue $\mathrm{Xu}^{1,2}$ \\ 1 Institute for Sedimentation on River and Coastal Engineering, Tianjin University, Tianjin 300350, China; \\ ysq20052707@163.com (S.Y.); xiaoxiaoxu_2004@163.com (H.X.) \\ 2 State Key Laboratory of Hydraulic Engineering Simulation and Safety, Tianjin University, \\ Tianjin 300350, China \\ * Correspondence: ychbai@tju.edu.cn; Tel.: +86-131-322-08381
}

Received: 12 July 2018; Accepted: 18 October 2018; Published: 23 October 2018

check for updates

\begin{abstract}
Studying the effects of different riparian vegetation densities on river channel evolution has practical significance for predicting the river channel evolution process during flood periods and ecological river engineering via the artificial planting of vegetation. In this study, we simulated the formation and evolution processes of river channels under different riparian vegetation coverage rates in laboratory conditions. The riparian vegetation coverage rates were set as $0,20,40$ and $80 \%$, on unilateral and bilateral sides of a river channel bank. Given the same flow and sediment boundary conditions, experiments were carried out in a $4 \times 1.5 \mathrm{~m}$ tank. This paper focuses on the comparative analysis of main stream stability characteristics, bend migration characteristics, river bank erosion characteristics and sediment transport intensity. The results showed that different amounts of riparian vegetation cover created different characteristics of river channel evolution and strongly impacted the stability of the banks and bed. River channel evolution under unilateral vegetation cover is often accompanied by alternate development of the main stream and branch, and the bend stability under unilateral riverbank vegetation cover is worse than under bilateral cover. For a bilateral vegetation-covered river channel, a narrow and deep regime channel more easily forms with a higher vegetation coverage rate; the curvature of the stable river bend is smaller, but the adaptation period of the flow to the river channel bed increases. Planting of riparian vegetation played a positive role in the erosion resistibility, which effectively reduced the lateral migration rate of the riverbank. The higher the vegetation coverage rate, the greater the flow shear stress needed for the same river channel migration rate. While effectively reducing lateral migration, riparian vegetation coverage increased the vertical migration and led to a trend in overall scour depth along the riverbank.
\end{abstract}

Keywords: river engineering; river channel evolution; hydrodynamic; riparian vegetation

\section{Introduction}

The process of river evolution is affected by many factors: flow, channel width, depth, slope, grain size and regional vegetation distribution. Riparian vegetation, in particular, plays a significant role in this process and considerably influences riverbank widening and river stability.

Riparian vegetation area increases the river resistance and effectively reduces the flow velocity [1], greatly reducing the sediment carrying capacity [2], thus affecting the sediment transport and deposition process [3,4] and final river bed morphology. The flow tends to shift to the main channel with minimal resistance [5], increasing channel brush depth and reducing the channel curvature, straightening the meandering channels $[6,7]$. Furthermore, vegetation roots affect riparian strength, thereby altering the bank's collapse conditions and riparian stability, so that the siltation 
is easily formed or destroyed, reducing riparian erosion, which in turn affects the channel lateral migration characteristics [8]. The effects of different vegetation types and densities on these river characteristics vary significantly. River channel banks with dense vegetation cover generally have lower river-widening rates than those with sparse vegetation $[9,10]$. Riparian vegetation can change the river's pattern by changing its width and depth ratio [11]. Many geomorphologists and engineers have long recognized the strong influence that vegetation exerts on river channel hydrodynamic characteristics and morphology. Further understanding of the influence is of great importance with respect to hydraulic and environmental engineering.

The role that riparian vegetation plays in the morphodynamic behavior of rivers was largely pursued through field studies, which explore the important of vegetation for bank process (stability/erosion); hydraulic efficiency of river channels; channel narrowing and sediment retention; and multi-thread rivers styles. For example, Dan and Wittenberg [12] highlighted the importance of shrubs in reducing flow velocities and thus further contributing to bank stability. Charlton et al. [13] observed some actual rivers in Britain and found that, for gravel rivers, if there are rows of trees on both sides, the width of a river is $30 \%$ less than the same river without trees, and tree presence more strongly affects sandy rivers. Other scholars $[1,10,14]$ also studied the effect of vegetation density on the river channel. The results showed that when the vegetation coverage was high, the channel was narrow and deep; when the vegetation coverage was low, the channel was wide and shallow. For actual river channels, the shallower the channel, the less stable the banks, the more easily anabranching and braiding develop, which are not conducive to navigation and dredging. Field research proposes new phenomena worthy of flume experimentation and modelling [15].

Modelling research focused on the role of vegetation as physical engineers of river channels, such as the impact of riparian vegetation on bank stability [16] and erosion resistance [17] or river planform [3], has allowed the processes to be investigated in detail. Furthermore, there are analytical modeling studies including the two-way interaction between vegetation and morphodynamics that show the effect of vegetation biomass on meander migration dynamics [18] and landscape topography [19].

Laboratory experiments have investigated the impact of vegetation on river channel morphodynamics in two aspects: flow structures under different discharge and vegetation (stem density, flexibility, canopy architecture, etc.) [20,21] and vegetation on river channel morphodynamics [22] and planform [23,24]. Experiments showed that riverbanks of emergent vegetation in overwidened, straight channels can induce channel narrowing and increased sinuosity $[25,26]$, and vegetation transforms the river planform by reinforcing sediment and so reducing channel widening and channel cutoffs [23]. Recently, the impacts of vegetation growth stage and rate have been explored [27-29], showing that as vegetation establishes under the same flow and sediment supply conditions, sediment retention increases; fewer, less mobile, narrower and deeper channels are maintained; and plants with small rooting depth are preferentially eroded, leaving deeper rooted plants, stabilizing sediment.

In a series of methods, although the actual measurement can reflect the actual influence, but due to the lack of repeated topography along the upstream section, we have not been able to quantify the differences fully in wall erosion between sprayed and vegetated reaches [30]. The experimental simulation can be repeated and the system variables can be flexibly adjusted to compensate for these shortcomings. Moreover, the field measurement is mostly aimed at the evolution of the local reach over a short time period, and it is difficult to complete long-term evolutionary analysis of the long time scale and including the river bend sequence. Theoretical analysis and mathematical simulation all rely on the understanding of physical processes and the establishment of the mechanical equations, whereas the physical process of vegetation in river channel evolution is quite complex.

At present, the study of vegetation's impact on the hydrodynamic characteristics of rivers is mainly focused on two aspects: the short-term effects of vegetation on the flow structure and bed morphology of the river and the long-term effects of vegetation on the stability of the river pattern 
and the change in river width and water depth in the process of river evolution. However, there is little research on the relationship between the evolution of the river dynamic axis and the stability of the main channel. At the same time, most of the river channel evolution experimental studies have been more focused on the analysis of the erosion characteristics of riverbanks and the role of vegetation in determining river planform and vegetation-related processes leading to channel blockage and avulsion, but not on the characteristics of bend migration and of typical straight sections of meandering rivers. For some dynamic processes, such as long-term evolution of a new river course under natural vegetation conditions after being newly-cut and the evolution of riparian vegetation in river channels during a flood period, an important research topic is how to deeply analyze the river bank erosion process, understand the relationship between riparian vegetation and river channel evolution, predict river channel bend and bank evolution trends and provide a reference for regional riparian ecological planning and regulation.

This paper reports on a series of physical model experiments conducted with the objective of understanding the influence of riparian vegetation density on the dynamic process of river channel evolution for a river that used to be straight. The riparian simulated vegetation was successfully cultivated by using cohesionless sand and planted with different coverage rates unilaterally and bilaterally on the initial river channel. The effects of different vegetation cover conditions on the hydrodynamic characteristics of river channel evolution, the stability characteristics of meandering flow, riparian erosion and sediment transport intensity were studied.

\section{Experiments}

\subsection{Experiment Facilities}

The experiments were conducted in a flume that was $4 \mathrm{~m}$ long and $1.5 \mathrm{~m}$ wide, made of steel, with sides that were $0.5 \mathrm{~m}$ in height. The flume slope was maintained by an adjustable jack support. A collection tank was arranged at the end of the experimental facility to store the water; the water was transported to the constant head tank, and the water flowed into the river channel through a pipe. The water discharge was controlled by a valve, and the excess water from the pump was directly diverted to the collection tank through the overflow pipe, which created a self-circulation of water (Figure 1).

The actual flow was divided into two parts while passing through the basin: one of which flowed along the bed and bank boundary of the river channel forming a channel flow, and the other one seeped into sand, forming a seepage. In this research, to better imitate a natural situation, to separate the seepage from the total flow, a $0.25 \mathrm{~m}$-wide seepage passage was set up around the flume with the filter screen arranged between the riverbed and passage to ensure water passed through and was intercepted by sand. Therefore, in theory, the total discharge is equal to the sum of the channel discharge and the seepage discharge:

$$
Q=Q_{R}+Q_{S}
$$

where $Q$ is the total discharge, $Q_{R}$ is the channel flow and $Q_{S}$ is the seepage discharge. 


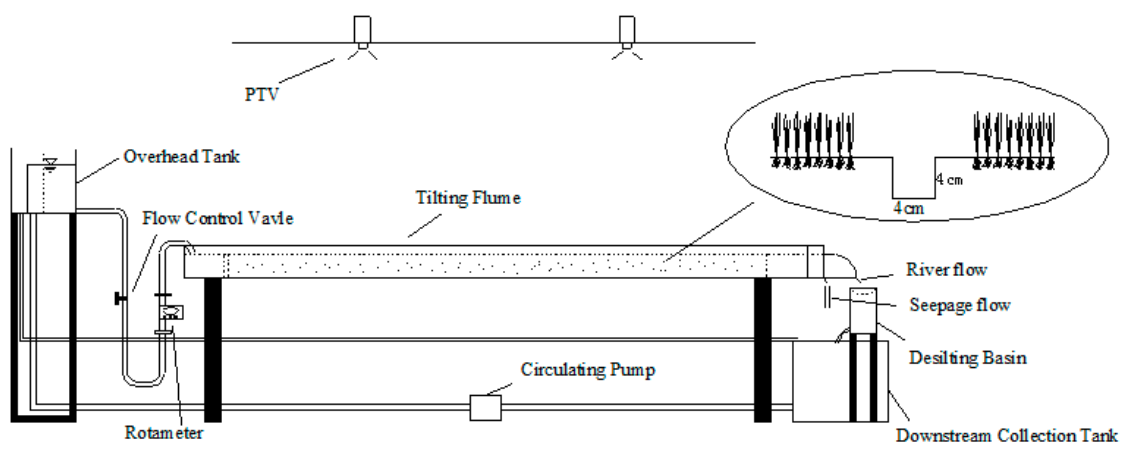

(a)

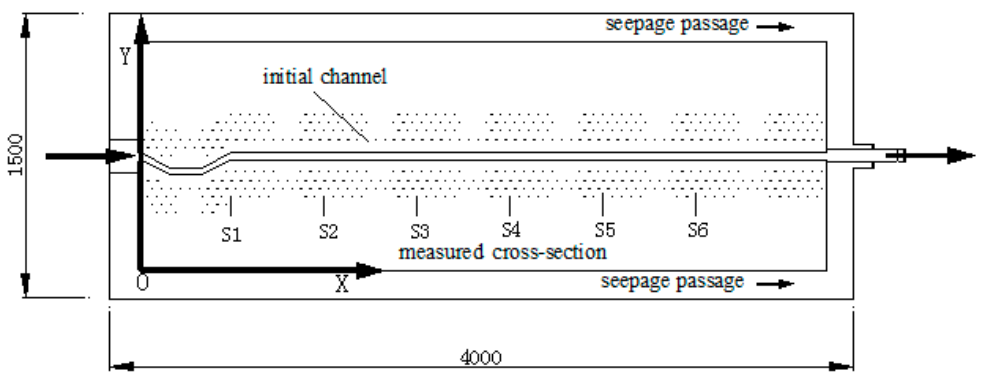

(b)

Figure 1. Schematic line diagram of (a) the experimental setup and (b) the initial channel cut in the layered flood-plain with riparian vegetation cover.

\subsection{Methods}

The initial channel was a square section $4 \times 4 \mathrm{~cm}$ in the center of the flume for every experimental run. The initial attack angle of the flow was adjusted to $30^{\circ}$ to accelerate the meandering process [31-33]. Van de Lageweg et al. [34] showed that discharge variation had no measurable effect on channel cutting and migration compared to a constant discharge experiment. We performed seven channel evolution experiments with different parameters (not shown in the article) to determine suitable discharge, slope and grain size. The main purpose of this paper is to study the effects of different riparian vegetation densities and layout on river channel evolution of a meandering river. Run 1 was chosen as the comparison group because it eventually formed a stable meandering channel. The evolution process maintained a constant discharge of $120 \mathrm{~mL} / \mathrm{s}$. The sand used in the model river channel experiment was fine sand selected according to the test conditions. The median grain size of the experimental sand was $\mathrm{d}_{50}=0.22 \mathrm{~mm}$ (transported predominantly as bedload), with a total thickness up to $0.15 \mathrm{~m}$. The particle gradation curve is shown in Figure 2. The bed was graded to an initial slope of 0.012, a typical value for experimental meandering channels (e.g., Schumm [35]), which remained almost constant throughout the experiments.

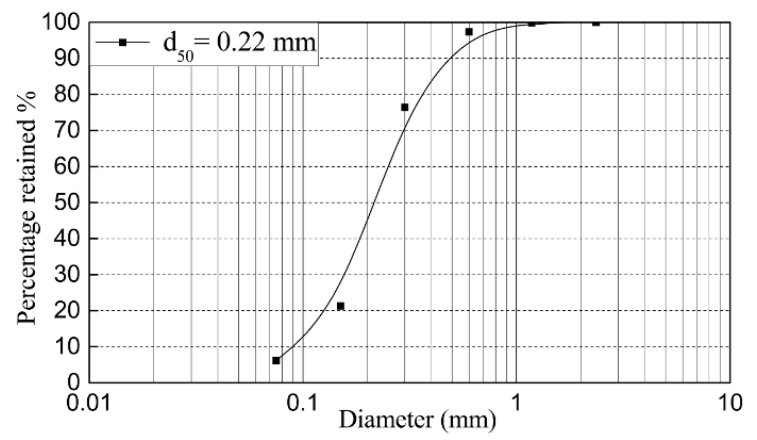

Figure 2. The particle gradation curve. 
As the bed was unstable, the river channel banks began to erode. Six cross-sections (S1-S6) were selected, and their evolution law was observed. At the same time, with the evolution of the river channel, discharge, velocity, width, depth, riparian elevation and sediment discharge were measured at certain times. The sediment transport rate varied with the stability of the channel, which was calculated every $30 \mathrm{~min}$ by measuring the sediment load of the downstream deposit cylinder. In order to maintain the overall balance of the sediment, dry sand was added to the channel upstream sand-supply system every half hour in equal quantities of collected sand from the deposit cylinder. The channel morphology and surface flow field were recorded every $20 \mathrm{~min}$ by the particle tracking velocimetry (PTV) system (with 2 CCD (charge coupled device) cameras fixed above), a new self-developed particle tracking velocimetry in our lab [36]. The distortion image obtained by the camera was processed by correction and coordinate transformation [37]. Therefore, the river channel bank lines could be identified to capture the overall process of the fluvial development. The particles were manually sprinkled onto the channel inlet, and the particle trajectories were recorded. Then, according to the application of the PTV system, the flow velocities were calculated.

In the experiments, the parameters like the Froude number, which stands for the kinetic energy of the river channel, and the Reynolds number, which stands for the cohesion of the sediment, were obtained through calculation. The Reynolds number varied from 500-4000 in these experiments. Therefore, the viscous resistance of the viscous sublayer could be ignored [38], and the surface tension of the small-scale rivers could be ignored based on the assumptions of Malverti et al. [39]. Table 1 shows the initial settings of the experimental runs, and the control variable for the runs was riparian vegetation coverage rate.

Table 1. Experiment cases.

\begin{tabular}{cccccc}
\hline Run No. & $\mathbf{d}_{\mathbf{5 0}}(\mathbf{m m})$ & $\begin{array}{c}\text { Discharge } \\
(\mathbf{m L} / \mathbf{s})\end{array}$ & Slope & $\begin{array}{c}\text { Duration } \\
(\mathbf{t} / \mathbf{m i n})\end{array}$ & Riparian Coverage \\
\hline 1 & 0.22 & 120 & 0.012 & 720 & None \\
2 & 0.22 & 120 & 0.012 & 960 & $80 \%$ unilateral \\
3 & 0.22 & 120 & 0.012 & 960 & $40 \%$ unilateral \\
4 & 0.22 & 120 & 0.012 & 960 & $20 \%$ unilateral \\
5 & 0.22 & 120 & 0.012 & 960 & $80 \%$ bilateral \\
6 & 0.22 & 120 & 0.012 & 960 & $40 \%$ bilateral \\
7 & 0.22 & 120 & 0.012 & 960 & $20 \%$ bilateral \\
\hline
\end{tabular}

Seven runs of experiments were completed to study the influence of riparian vegetation coverage on the process of formation and evolution. The first run (1) had no vegetation cover, and another 3 runs (2, 3 and 4) included different densities of vegetation on one side of the riverbank (left bank), whereas the other 3 runs $(5,6$ and 7$)$ had banks covered with different densities of vegetation on both sides of the river. The arrangement of vegetation was quincunx $0.18 \mathrm{~m}$ wide and $3 \mathrm{~m} \mathrm{long,} \mathrm{with} \mathrm{a}$ distance of $1 \mathrm{~cm}$ of planting mesh (Figure 3). The whole vegetation area was $4 \mathrm{~cm}$ away from the initial channel to eliminate errors of analysis on the development of the river channel caused by the rapid widening of the initial channel.

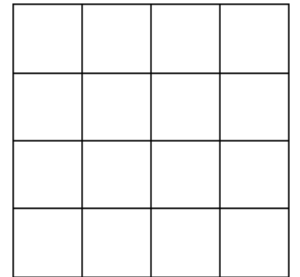

$0 \%$

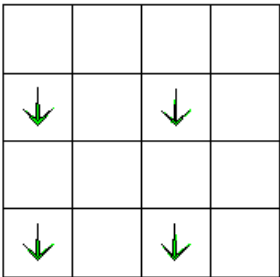

$20 \%$

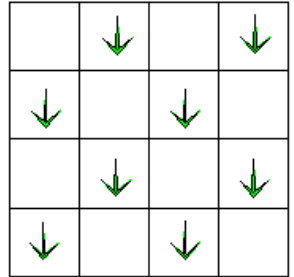

$40 \%$

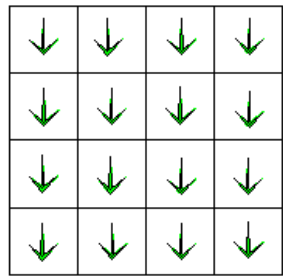

$80 \%$

Figure 3. Sketch map of vegetation arrangement. 
As for vegetation, Agrostis stolonifera was chosen due to its fast germination and development. Agrostis stolonifera can adapt to the sandy bed, and the growth state can be maintained as long as a month, sufficient to meet the requirements of the test cycle, as long as the sand is kept in a certain amount of moisture. Though experimental observation, germination was achieved after 2-3 days with short roots of about $1 \mathrm{~cm}$ at about $23^{\circ} \mathrm{C}$ in summer. In the early stage of growth, plants of $\mathrm{A}$ do not develop a substantial stem, and after 8 days of growth, it will remain in the grass state and will not continue to grow rapidly. However, it grows slowly in winter; seed germination takes about 10 days, reaches the grass state after 20 days and needs heating to accelerate its germination and development during the whole growth process. Therefore, it is generally tested in summer. The scour depth is closely related to the root sizes $[40,41]$, and the vegetation collapse and uprooted time affect the relative timescale of scour-inducing floods and can set the subsequent course of channel and riparian ecosystem evolution [42]. Therefore, grass with the state of no longer growing fast was used as riparian vegetation for analysis to exclude the influence of timescale and other conditions on the experimental results.

Agrostis stolonifera has similar biological growth characteristics to Avena sativa $\mathrm{L}$ and Alfalfa, which was used by other scholars $[23,28,29,43,44]$ to represent riparian vegetation, making it convenient for reaching the limit where the biological and the hydrological timescales are comparable over the limited duration of the experiment [27]. A study by researchers at the U.S. Department of Agriculture [45] showed that the cohesion provided by Alfalfa roots to non-cohesive sand is comparable to the magnitude of root-reinforcement provided to natural streambanks relative to the strength of the bank material alone. Therefore, Agrostis stolonifera is also a realistic way of simulating vegetation in the laboratory. The effective root coverage is taken as the vegetation coverage. Vegetation coverage averages from $0-100 \%$ to analyze the nonlinear effect of linear density change on river channel evolution. The sketch map of vegetation arrangement is shown in Figure 3. The mean diameter of effective root cover $\mathrm{d} \approx 1 \mathrm{~cm}$. The calculated four effective coverage rates were $0,20,40$ and $80 \%$ $\left(\mathrm{K} 1=0 \% ; \mathrm{K} 2=4\left(\pi \mathrm{d}^{2} / 4\right) / \mathrm{A} \approx 20 \% ; \mathrm{K} 3=2 \times \mathrm{K} 2 \approx 40 \% ; \mathrm{K} 4=4 \times \mathrm{K} 2 \approx 80 \%\right)$.

Each individual plant with 5 grass seedlings was planted to achieve the reinforcement effect of the vegetation on the riverbank; the diameter of each grass seedling was about $0.56 \mathrm{~cm}$, and the average height was $6.47 \mathrm{~cm}$ with roots whose average length was $2.7 \mathrm{~cm}$, which represented the effective reinforcement rate from the vegetation on the riverbank.

\section{Results}

\subsection{Phenomenon Analysis}

Due to the cohesion of the riverbank, erosion occurred only when the stress produced by the shear flow exceeded a critical value [46]. Observing the evolution of a meandering river channel, the river bend developed from upstream and downstream in the initial stage. With the development of meander, the flow condition downstream gradually matured, while the curvature of river increased. The downstream evolved according to its own evolution mechanism and played an important role in restricting the upstream. The inflow angle had a short-term effect on the evolution of the river channel and accelerated the development in the initial stage, but the river would reach a balance according to the flow and sediment condition in the long run. Table 2 shows the changes in the basic variables in the evolution of the seven groups of experiments and the retained planform. 
Table 2. Experimental parameters.

\begin{tabular}{cccccc}
\hline Run & Depth $(\mathbf{m m})$ & Velocity $(\mathbf{m} / \mathbf{s})$ & Reynolds Number $\left(\frac{\mathbf{V R}}{\vartheta}\right)$ & Froude Number $\left(\frac{\mathbf{V}}{\sqrt{\text { gh }}}\right)$ & Retained Planform \\
\hline 1 & $6-15$ & $0.25-0.34$ & $1294-3901$ & $0.78-1.20$ & Meandering \\
2 & $9-13.7$ & $0.21-0.36$ & $1562-3244$ & $0.65-1.17$ & Meandering \\
3 & $5-14$ & $0.19-0.33$ & $808-2904$ & $0.65-1.43$ & Meandering-Anabranching \\
4 & $3.3-14$ & $0.19-0.34$ & $538-2871$ & $0.69-1.21$ & Meandering-Anabranching \\
5 & $8-14$ & $0.26-0.41$ & $1611-3017$ & $0.69-1.43$ & Straight-Meandering \\
6 & $8.3-16$ & $0.18-0.29$ & $1759-2487$ & $0.47-1.05$ & Straight-Meandering \\
7 & $6.3-14$ & $0.13-0.28$ & $800-2573$ & $0.42-0.78$ & Straight-Meandering \\
\hline
\end{tabular}

During the experiment, the bottom of the riverbank began to be scoured by the flow, creating a cantilever structure. Collapse would occur if the riverbank showed instability [47]. However, for those channels with vegetation on their bank, even though scouring would still occur and the vegetation's roots would be exposed to the air, which would lead to a local scour (Figure 4a), less slump block phenomena occurred due to the reinforcement effect created by the vegetation roots. Therefore, the influence of vegetation on the erosion rate of river banks is closely related to its density, root development and arrangement mode. The scouring process could be divided into two processes: vegetation scouring and isolation, and vegetation collapse and washing away by flow. About 1-10 min passed before the plant showed instability. Since the initial velocity was about $0.35 \mathrm{~m} / \mathrm{s}$, the plant scoured easily and fell very quickly. About 2-20 min later, the plant washed away after it fell down, and the falling plant in the bed increased the local roughness and protected the bank from scouring (Figure 4b). Consequently, the vegetation increased the local flow disturbance. At the initial period of the evolution of the river channel, the width and depth were relatively small and the flow was in a state of supercritical flow, which created a turbulent area in the vegetation riparian zone, and the bed sand particles encountered upward vortexes in the process leaping from the bed. When the sand fell out of the vortex, it entered the main stream, resulting in intense scouring along the vegetation belt. The main streamline scattered due to the flow turbulence caused by the vegetation, and staggered deposition occurred along the center of the channel, which led to the slow development of river meander. However, the vegetation had a reinforcing effect on the riverbank, which increased the resistance along the riverbank. As the evolution of the river channel continued, plants falling in the channel increased the local hydraulic roughness, and the flow velocity among the vegetation decreased, which increased the amount the deposition and markedly decreased the erosion rate along the riverbank.

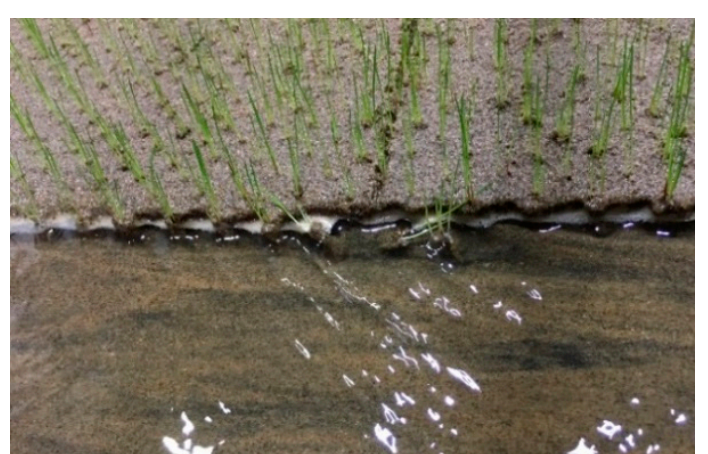

(a)

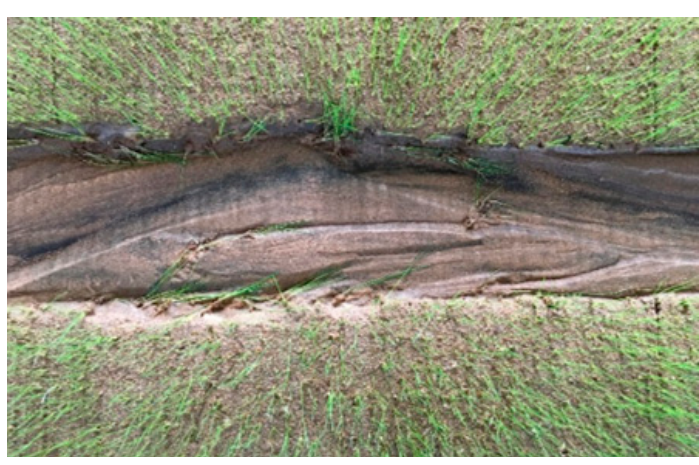

(b)

Figure 4. (a) Water washes the river bank-covering vegetation. (b) Vegetation revetment during channel evolution.

\subsection{Hydraulic Characteristics of Flow}

During the experiment, particles were manually scattered onto the river channel inlet, and most of the particles flowed to the axis of the water flow. The surface flow field was measured with PTV, and the particle trajectories were recorded by the fixed cameras. The trajectories were extracted, and the 
dynamic axis of flow at different times was plotted (Figure 5a,b). Through the observation of different groups of river channel evolution, we found that, due to the influence of the upstream inflow angle, the upstream began to bend, thus affecting the downstream. The downstream evolution also had a constraining effect on the upstream, in accordance with the evolution mechanism of the river channel itself. In the initial stage, the downstream evolution lagged behind the upstream, and the curvature of bend had downward transitivity. The influence of inflow angle on the evolution of river bend was only short term. At the initial time, the evolution of the river bend was accelerated, but in the longer runs, the river channel reached its equilibrium state under different boundary conditions, such as water flow, sediment, etc. After the initial $80 \mathrm{~min}$, the downstream river bank was basically limited to river bank collapse [38], which was mainly due to upstream disturbances that had not yet fully propagated to the downstream. Observations of Run 1 demonstrated that, during river channel evolution, the flow dynamic axis was close to the inner-bank and leaned toward the downstream along the inner-bank rushing point (Figure 5a). At $360 \mathrm{~min}$, the flow dynamic axis maintained the same curvature, and a wavelength developed along the whole river channel; a typical meandering river channel formed.

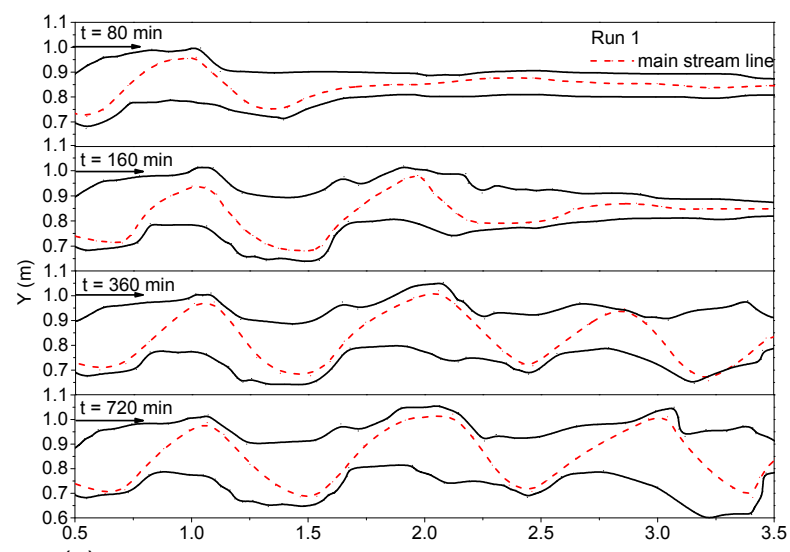

(a)

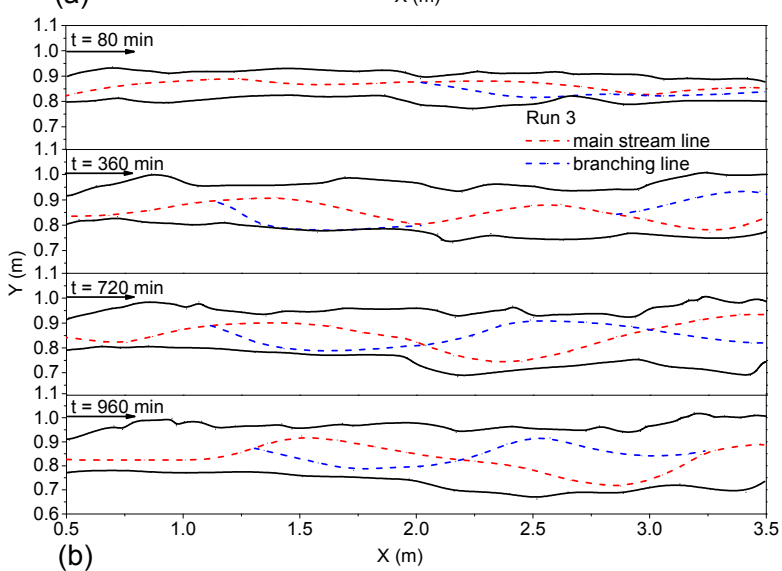

Figure 5. Dynamic axis of flow in bends under different moments: (a) Run 1 and (b) Run 3.

The evolution process of Run 3 is shown in Figure 5b. The river channel evolved at 80 min; the main stream adjustment was accompanied by the formation of the downstream branch; and the branch node gradually moved upstream. Just at $180 \mathrm{~min}$, the river formed a steady channel thread. At $360 \mathrm{~min}$, due to the influence of the downstream branch, along the whole reach, two larger anabranches gradually formed. Between 1.5 and $2.0 \mathrm{~m}$ of the river reach, the main stream should have been bent, but due to the barrier of the vegetation bank, it developed straight. As seen from Figure 6, along the left bank, three large silting bodies (dynamic sediment bodies) formed, and the water had to readjust its main path on the side of the silting bodies. As the evolution continued, at $600 \mathrm{~min}$, the silting bodies near the right bank gradually disappeared, and those near the left bank gradually 
increased, forming a new silting body (Figure 6, Dynamic Sediment Body 4). This phenomenon is often seen in actual rivers, as shown in Figure 6b. On the Mataura River near a cattle flat, a tributary of the Red River, the vegetation zone is distributed on one bank side, whereas the other side contains meadow, and the main stream moves to the bank of the meadow, which has a lower scour resistance.

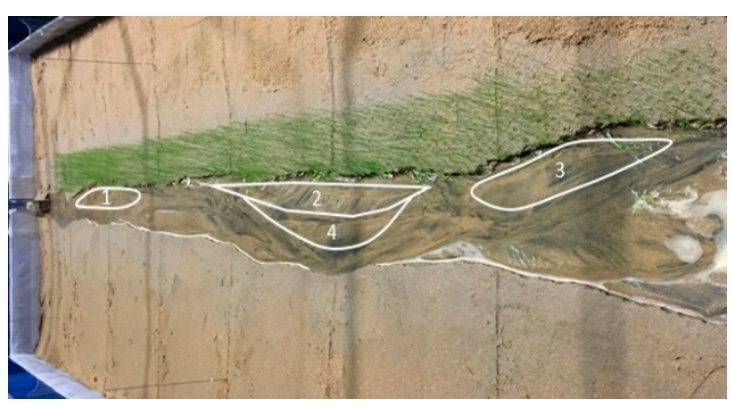

(a)

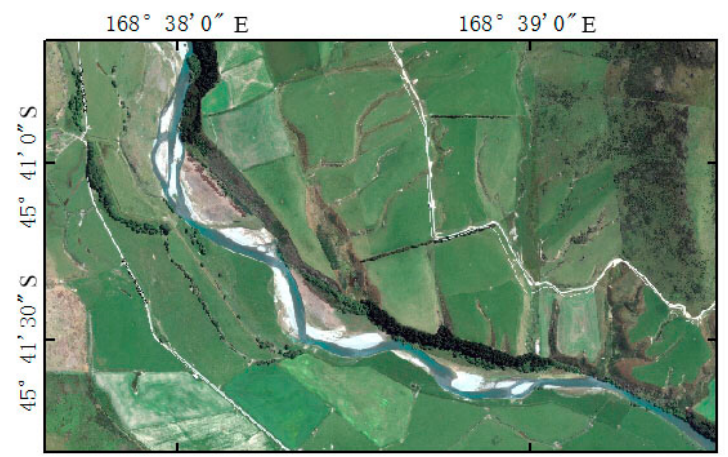

(b)

Figure 6. Channel morphology ((a) Run 3 at $t=600 \mathrm{~min}$ ); (b) the Mataura River near cattle flat (from Google Earth)).

The asymmetry of riverbank erosion resistance (riverbank anti erosion properties) led to the swing of the main stream and the alternate development of the main stream and tributaries. The river channel will maintain the anabranching or braided pattern for a long time (Figure 5b). However, this is not caused by the greater difference in erosion resistance on both river bank sides, but by the more frequent adjustment of the river regime. Taking Run 2 as an example, given the dense vegetation distributed on the left bank, the interaction between the two sides of the river bank did not produce a larger mutual disturbance, and the main stream deviated away from the left bank to seek a new hydrodynamic environment.

The existence of riparian vegetation slows down the lateral migration of the river. In laboratory experiments, the riparian vegetation has played a role in stabilizing the point bar, strengthening the river bank resistance, which will cause the river to develop in the direction of low bending. The time for the formation of a more stable flow dynamic axis of vegetated revetment river was longer than that without vegetation; especially for the situation where vegetation revetment was asymmetric on the left and right banks, and even the main stream line had had a meandering trend. Due to the influence of local vegetation flow resistance, the flow velocity along the cross-section was redistributed and the original bending trend was destroyed. Runs 2, 3 and 4 completed the riverbed adjustment at 400 , 180 and $600 \mathrm{~min}$, respectively. Figure 7a,b shows the bed morphology of the 1.5-2.0 m reach in the case of riparian vegetation coverage of $40 \%$ in both unilateral and bilateral riparian areas. It can be seen that the Run 3 river bed was still in a state of disorder without a main stream trend, and Run 6 formed a clear main stream trend. It was found from the experimental observation. We found that when the vegetation was distributed on one side of the river bank, riparian vegetation cover along the river bank was dominant, and the adjustment process of flow dynamic axis was: scattered $\rightarrow$ micro bending/branching $\rightarrow$ meandering $\rightarrow$ straight (with scattered) $\rightarrow$ micro bending/branching. 


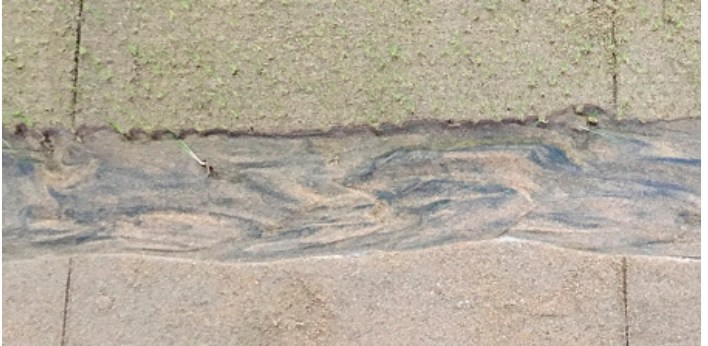

(a)

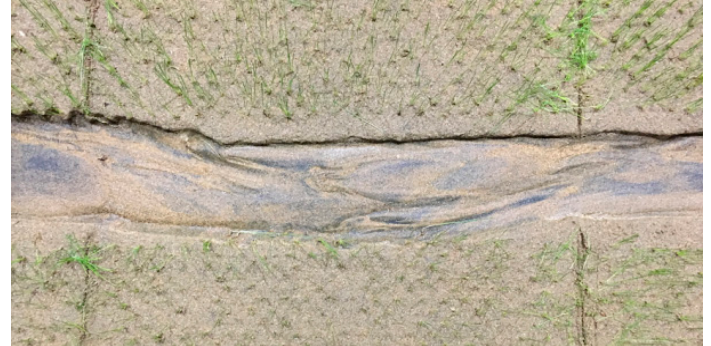

(b)

Figure 7. At $80 \mathrm{~min}$, bed morphology of the 1.5-2.0 m reach. Riparian vegetation coverage of $40 \%$ in (a) unilateral riparian areas and $(\mathbf{b})$ bilateral riparian areas.

Figure 8 shows the bed morphology of the 1.5-2.5 m reach of three groups of different riparian vegetation coverage at the stable time. The black part of the bed sand shows the main trajectory of sediment transport for extremely fine sediment, which reflects the concentration of the main stream and the increase in flow velocity under $80 \%$ vegetation coverage, which enhanced the sediment-carrying capacity and led to the concentrated scouring effect of the channel. As can be seen from Figure $8 \mathrm{a}-\mathrm{c}$, in the absence of vegetation, the surface scour of the bed had a large scale and greater quantity, and the vortex action of the bend was obvious. When the river bank was planted with vegetation, the disturbance of vegetation to water flow destroyed the large-scale vortices that should have formed in the bend. The greater the vegetation coverage was, the more obvious the effect was; when the riverbank vegetation coverage was $80 \%$, the riverbed had no obvious large-scale scoured pits.

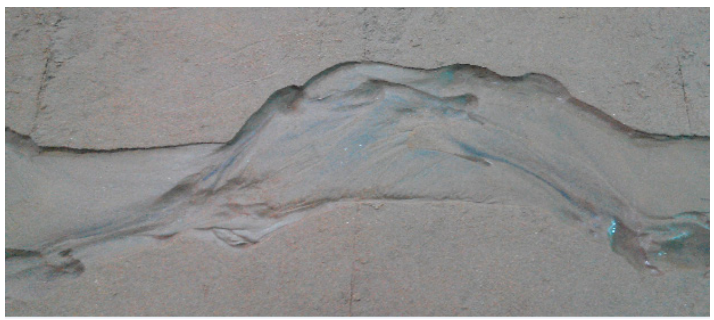

(a)

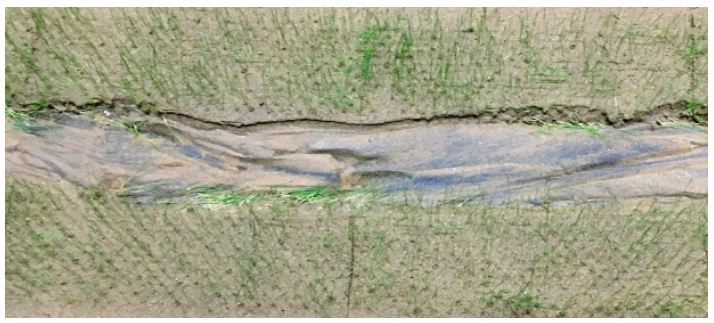

(b)

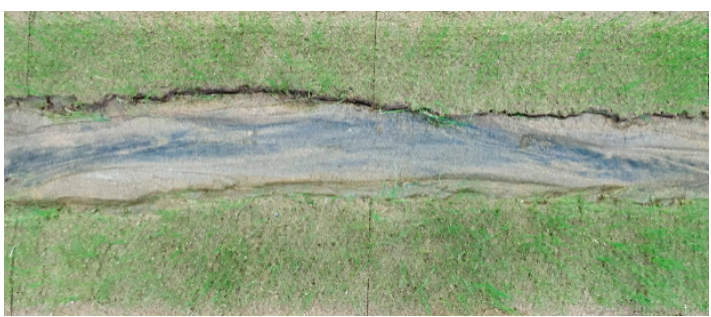

(c)

Figure 8. Bed morphology of the 1.5-2.5 m reach at the stable time: (a) no vegetation cover, (b) riparian vegetation coverage of $40 \%$ in bilateral riparian areas and (c) riparian vegetation coverage of $80 \%$ in bilateral riparian areas. 
As seen in Figure 9, Runs 2, 3 and 4 included three groups of one-sided vegetation cover (left bank vegetation cover), showing the main stream, tributaries and final riparian erosion. At $960 \mathrm{~min}$, a large deflection of the main stream formed, and the erosion rate of the two bank sides was different. Specifically, the center of the channel at the initial time was located at $y=0.85 \mathrm{~m}$. Finally, the evolutions of the main stream lines were all inclined to the right bank. The curvature of the right bank line showed non-uniform distribution, and the curvature was larger; the left bank presented overall erosion recession, and the curvature was smaller. The difference in the erosion rate of the two bank sides will be analyzed in detail in Section 3.3.

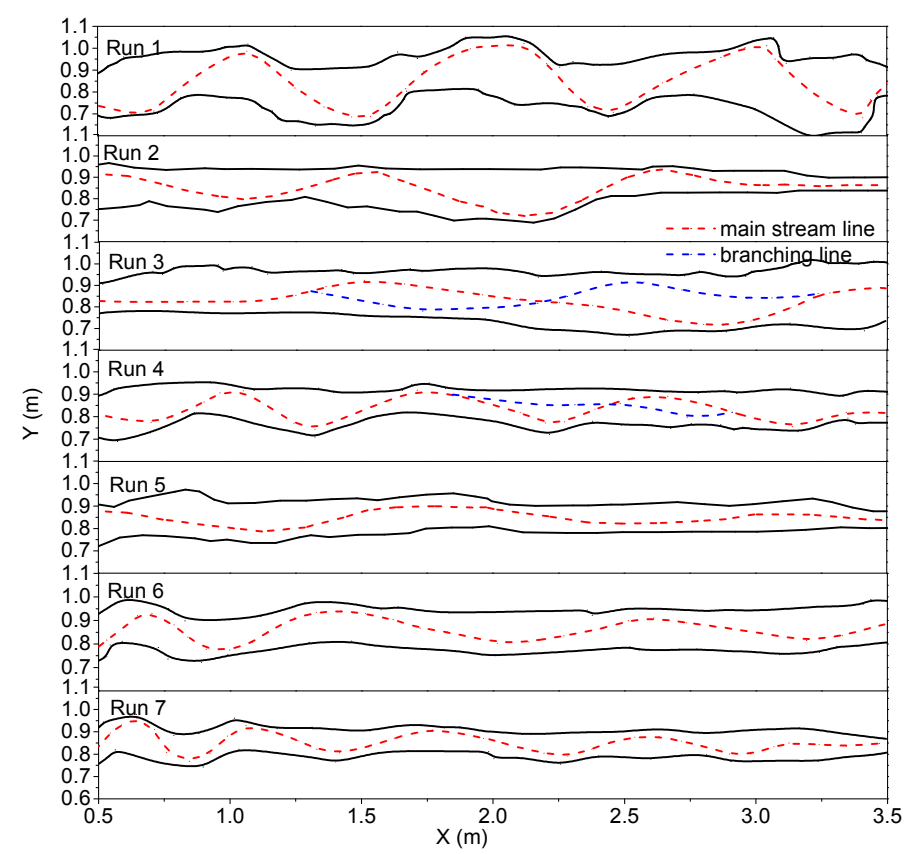

Figure 9. River bank-lines and dynamic axis for seven different experimental runs at the final relative stability moment.

The relationship between the final curvature of river channel main stream and the vegetation coverage rate of bilateral riverbank cover is shown in Figure 10. As can be seen from the diagram, vegetation coverage effectively reduced the curvature of the river channel. With the increase in the coverage rate, the curvature of the river decreased gradually and tended to one (Figure 11a,b). When the vegetation coverage reached $80 \%$, the curvature was 1.01 , indicating that the river was close to a straight river type.

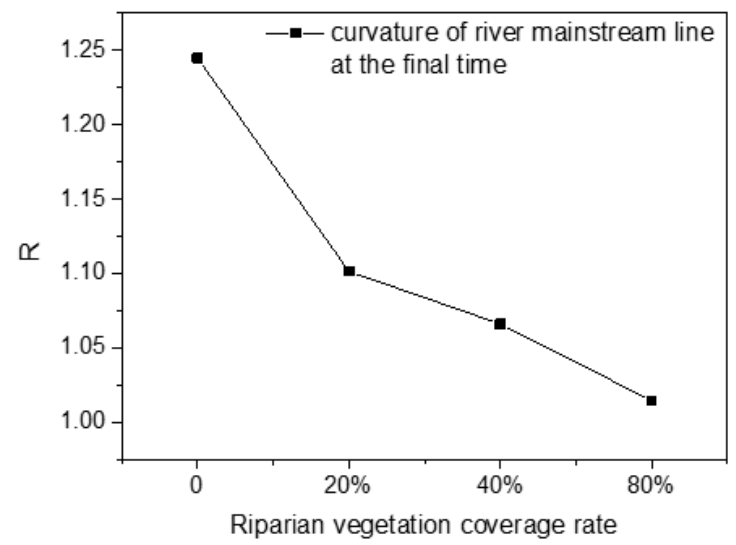

Figure 10. Relationship between river channel curvature and riparian vegetation coverage rate of bilateral cover. 


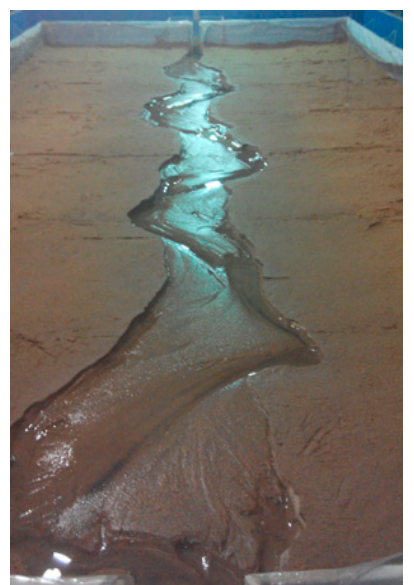

(a)

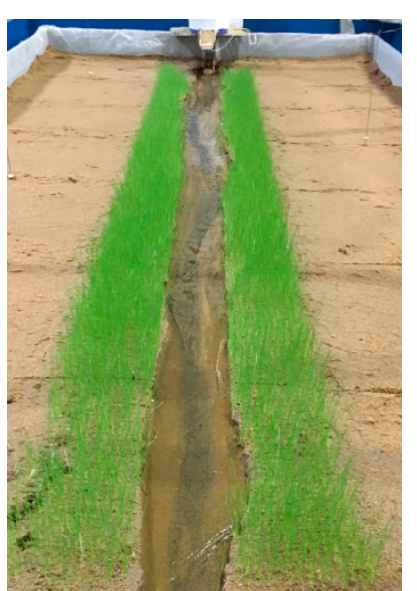

(b)

Figure 11. Final relative steady state: (a) $0 \%$ riparian vegetation coverage rate; (b) $80 \%$ riparian vegetation coverage rate).

Ikeda et al. [48] argued that the rates of meander migration depend on the velocity perturbation $u^{\prime}$ from the mean velocity (the different between the velocity near the outside bank and the mean velocity). $u^{\prime}$ represents the magnitude of the shear forces of the flow acting on the river banks [49] in $\mathrm{m} / \mathrm{s}$. An erodibility coefficient $E_{0}$ can be defined as the anti-erosion ability of the bank shear forces and has a strong relationship with vegetation coverage. The rate of meander migration $M$ is the ratio of riparian erosion area to average riparian length in a given period of time [50], in $\mathrm{mm} / \mathrm{min}$. The rate of meander migration can be expressed as:

$$
M=E_{0} u^{\prime}
$$

For given channel geometry and flow conditions, the velocity distribution within a bend determines the distribution of flow shear forces on the river banks and bed [51]. In this paper, the liner model of meander migration was used to explain the integrated influences of channel curvature on lateral migration rates [48]. The model was based on the perturbation expansion on the curvature of the equation of motion for flow and sediment and was used to estimate linear cross-section profiles for depth-averaged flow velocities and bed elevations. The model has been recognized and validated by scholars with actual rivers [48,52-54]. We analyzed the relationship between the rates of meander migration and the velocity perturbation based on experimental measurement data and comparisons with actual river conditions [50] and analyzed the meander migration characteristics in different riparian vegetation coverage.

The velocity perturbation $u^{\prime}$ equals the maximum near-bank velocity minus the mean cross-section velocity, that is $u^{\prime}=u_{\max }-\bar{u}$. The maximum near-bank velocity is considered as the maximum near-bank surface velocity. The mean velocity is the discharge divided by the channel cross-section area. According to the difference in the final curvature along the river channel, which was divided into three sections for analysis $(0.5-1.5 \mathrm{~m}, 1.5-2.5 \mathrm{~m}$ and $2.5-3.5 \mathrm{~m})$, we respectively calculated the corresponding migration rate and velocity perturbation at different time intervals, because of the rapid widening of the channel at the initial stage and the riparian vegetation having fewer effects on the flow. Therefore, the relationship between the velocity perturbation and meander migration rate was analyzed only at 80-960 min. The time period was divided into three time intervals: 80-360 min, 360-720 min and 720-960 min. The maximum and mean velocity at the end of each stage were used for calculating the velocity perturbation.

The results reflect a strong effect of riparian vegetation on rates of river channel migration. As shown in Figure 12, for similar magnitudes of flow shear stress (expressed by velocity perturbation $u^{\prime}$ ), the migration rate for $20 \%$ riparian vegetation coverage was generally higher than that for $80 \%$ riparian 
vegetation coverage. The migration rate for a $40 \%$ riparian vegetation coverage rate was mostly higher than for an $80 \%$ riparian vegetation coverage. For the similar meander migration rate, the greater the vegetation coverage rate, the greater the flow shear stress, which is why riparian vegetation coverage leads the channel to become narrow and deep. The linear regressions corresponding to the three vegetation coverages were all positively related, indicating that the overall larger meander migration required a large flow shear stress. The slope of linear regressions drawn for the $40 \%$ riparian vegetation coverage rate values tended to be steeper, indicating that the channel meander migration rates under this coverage were more sensitive to increases in flow shear; the whole channel formed a large inhomogeneous lateral migration. The slope of linear regressions drawn for $80 \%$ and $20 \%$ riparian vegetation coverage rates were relatively smooth. The $80 \%$ riparian vegetation coverage had the lowest meander migration rates.

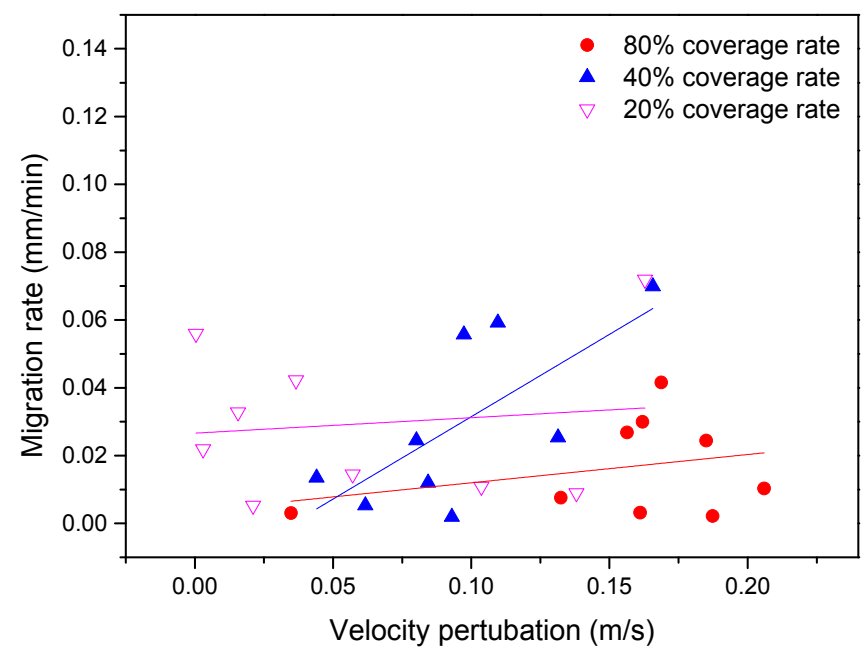

Figure 12. Migration rate versus velocity perturbation, 80-960 $\mathrm{min}$.

\subsection{River Bank Evolution}

The evolution of a meandering river channel is characterized by overall erosion recession of the river bank and the enlargement of the meandering amplitude (Figure 4a). As the initial river bend is not in accordance with the river facies relation, the river channel gradually evolved from the initial straight river channel. The river widening process showed a trend of nonlinear exponential decrease [55]. During the initial stage, a rapid widening of the channel would take place and the water flow could complete the initial bed-forming role in the short term [56,57]. After $80 \mathrm{~min}$, the river channel extending was shown by the development of sediment erosion and deposition. We observed that the evolution of river banks can be divided into three periods: rapid extension, transition and stable. Therefore, according to the experimental observation of river channel evolution law, the river channel evolution was divided into four time intervals: 0-80 $\mathrm{min}, 80-360 \mathrm{~min}, 360-720 \mathrm{~min}$ and 720-960 min, to study the variation law of the channel widening rate. Each stage takes its intermediate time as the correspondent time of the average river bank migration rate.

The average channel widening rate $(d B / d t)$ during the whole period was calculated, and the widening rate of the river banks corresponding to different river channel evolution times was plotted for bilateral vegetation cover (Figure 13a) and unilateral vegetation cover (Figure 13b), in which the rate of river banks migration at corresponding points indicates average riparian erosion rates over a period of time. As seen in Figure 13a, the average widening rate of the four sets of bilateral riparian vegetation cover decreased exponentially with time. For the narrow and deep channel with small initial width, the vegetation disturbance of the two groups with denser vegetation coverage $(80 \%, 40 \%)$ was greater than that for sparse vegetation cover $(20 \%)$ and no vegetation cover. With river channel widening, the disturbance of the water flow weakened and the inhibition of vegetation on the erosion 
of river banks enhanced, and the greater the vegetation coverage rate, the smaller the rate of channel bank migration. For the full time intervals, the average channel bank widening rate for no vegetation cover was 2.2 -times that of the $80 \%$ vegetation coverage, 1.79 -times that of the $40 \%$ vegetation coverage and 2.09-times that of the $20 \%$ vegetation coverage (Table 3 ). The coverage of riparian vegetation effectively slowed the widening rate of the river bank. As seen in Figure $13 \mathrm{~b}$, for unilateral vegetation cover, the average widening rate of the river banks was $40 \%>80 \%>20 \%$.
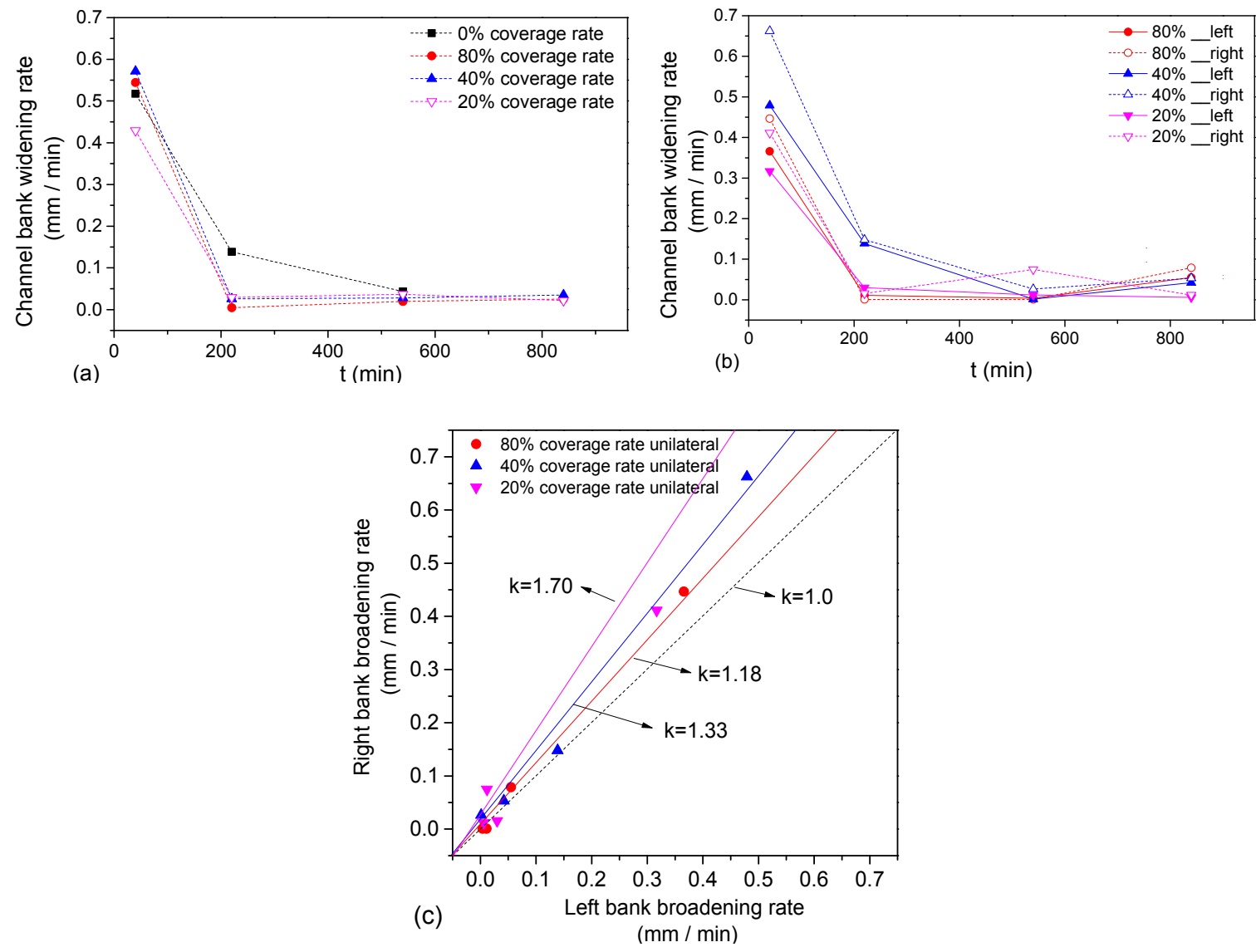

Figure 13. Temporal evolution of river banks: (a) bilateral vegetation cover and (b) unilateral vegetation cover; (c) the relationship between the widening rate of right bank and left bank.

Table 3. Average channel bank widening rate of bilateral vegetation cover.

\begin{tabular}{cc}
\hline Run & $d B / d t(\mathbf{m m} / \mathbf{m i n})$ \\
\hline $1(0 \%)$ & 0.133 \\
$7(20 \%)$ & 0.0746 \\
$6(40 \%)$ & 0.0636 \\
$5(80 \%)$ & 0.0604 \\
\hline
\end{tabular}

The unilateral coverage of the riparian vegetation led to asymmetry of the river bank evolution. The average widening rate of the left bank corresponding to different times was taken as abscissa and the average widening rate of the right bank as the ordinate, as shown in Figure 13c. We fitted the ratio curve of the average widening rate of the left and right banks. For $80 \%$ vegetation coverage, the average widening rate of the right bank was 1.18-times that of the left bank; and for $40 \%$, the average widening rate of the right bank was 1.33-times that of the left bank. For $20 \%$, the average widening rate of the right bank was 1.7-times that of the left bank (Table 4). We found that the ratio for the average widening rate of the left and right banks decreased with increasing vegetation coverage. 
Table 4. Average channel bank widening rate of unilateral vegetation cover.

\begin{tabular}{ccc}
\hline \multirow{2}{*}{ Run } & \multicolumn{2}{c}{$d B / d t(\mathbf{m m} / \mathbf{m i n})$} \\
\cline { 2 - 3 } & Non-Vegetation Bank (Right Bank) & Vegetation Bank (Left Bank) \\
\hline $4(20 \%)$ & 0.0698 & 0.041 \\
$3(40 \%)$ & 0.1216 & 0.0916 \\
$2(80 \%)$ & 0.0575 & 0.0489 \\
\hline
\end{tabular}

\subsection{Near-Bank Bed Evolution}

The effects of riparian vegetation cover on near-bank bed evolution are shown in Figure 14a. The four groups of experiments (Runs 1, 5, 6 and 7) reached relative dynamic stability after running $720 \mathrm{~min}$, so we collected the near-bank bed elevation under different riparian vegetation cover to make a comparison. It was obvious that the vegetation coverage had a strong influence on the near-bank elevation, leading to the increase in the trend of overall scour depth and bed surface fluctuation. The fluctuation amplitude of the bed elevation increased with the vegetation coverage. The influence of vegetation coverage was nonlinear. Smaller vegetation coverage was likely to form deep scour locally. Large-scale fluctuations in the near-bank bed elevation curves were related to the curvature radius of meander, and the distribution of pools along the elevation curves reflected the periodic distribution of the bend wavelength. However, the two were not in complete agreement with each other, and the pools were not only at the bend apex. In addition to large-scale fluctuations, there were also some small-scale fluctuations that had smaller fluctuation cycles, such as Run 6 . The small pool at $x=1.7 \mathrm{~m}$ shows the history of river bend evolution. For no vegetation coverage (Run 1) in Figure 14a, except for large-scale fluctuations, there were a large number of small periodic fluctuations along the channel bank. The alternating development of deep troughs and the shoals showed the historical process of the development of scouring and silting of channel sediment.

The longitudinal variation in near-bank bed elevations of Runs 1 and 5 are shown in Figure 14b,c, respectively. We measured the near-bank elevation for four typical moments (80 min, $360 \mathrm{~min}, 720 \mathrm{~min}$ and $960 \mathrm{~min})$. The initial time ( $80 \mathrm{~min}$ ) and relative stability time $(720 \mathrm{~min}$ ) were used to investigate the influence of time on bed morphology. Figure $14 \mathrm{~b}, \mathrm{c}$ show that the variation trends in the left and right bank profiles were basically the same. The main difference was a periodic phase lag existing between them. For Run 1 (Figure 14b), under the action of flow and upstream sediment addition, the mean bed elevation did not change, and the undulation magnitude of bed elevation increased sharply. On the contrary, for Run 5 (Figure 14c), the bed elevation had an obvious tendency of upward migration from $80 \mathrm{~min}-720 \mathrm{~min}$, and the undulation of bed elevation became rougher, while the undulation magnitude remained the same with time. For the no vegetation condition, the bed topography changed weakly at the beginning, then gradually increased. For the river covered with riparian vegetation, because of the severe disturbance of the banks, the bed topography changed intensely, with the maturity of pools and point bars, and the flow and bed were still in the dynamic equilibrium state.

Taking the Run 3 case as an example, the influence of the unilateral vegetation cover on the near-bank bed elevations was analyzed, as shown in Figure 15. Run 3 is covered with vegetation on the left bank and no vegetation on the right bank. The vegetation coverage of the river channel was different; the corresponding bank strength was different; and the corresponding near-bank elevation was also very different during the river channel evolution. As can be seen from Figure 15, the near-bank elevations of the left bank were obviously lower than those of the right bank. This may be because, although the riparian vegetation increased the riverbank erosion resistance, it also increased the instability of flow and the disturbance to the river bank. In the initial stage, the intense disturbance action was mainly reflected in many small-scale undulations along the river bank. With the constant erosion of the left bank, these riverbed undulations propagated to the center of the river channel; thus, the cross-section flow structure and the bed morphology near the right bank were disturbed. At 360 min, alternately distributed large-scale point bars and pools developed on the left, while there were 
also unstable large-scale pools appearing on the right. As the evolution continued, the bed morphology constantly changed and adapted to the flow structure. At $720 \mathrm{~min}$, large-scale point bars and pools disappeared and converted to small-scale bed undulation. The development of left and right banks was more uniform this time. Subsequently, due to the imbalance of riparian characteristics, the river bed continued to adjust and develop. For this unilateral vegetation-covered channel, the imbalance in riparian characteristics led to the continuous disequilibrium evolution of bed morphology and to the unstable evolution of the river dynamic axis.
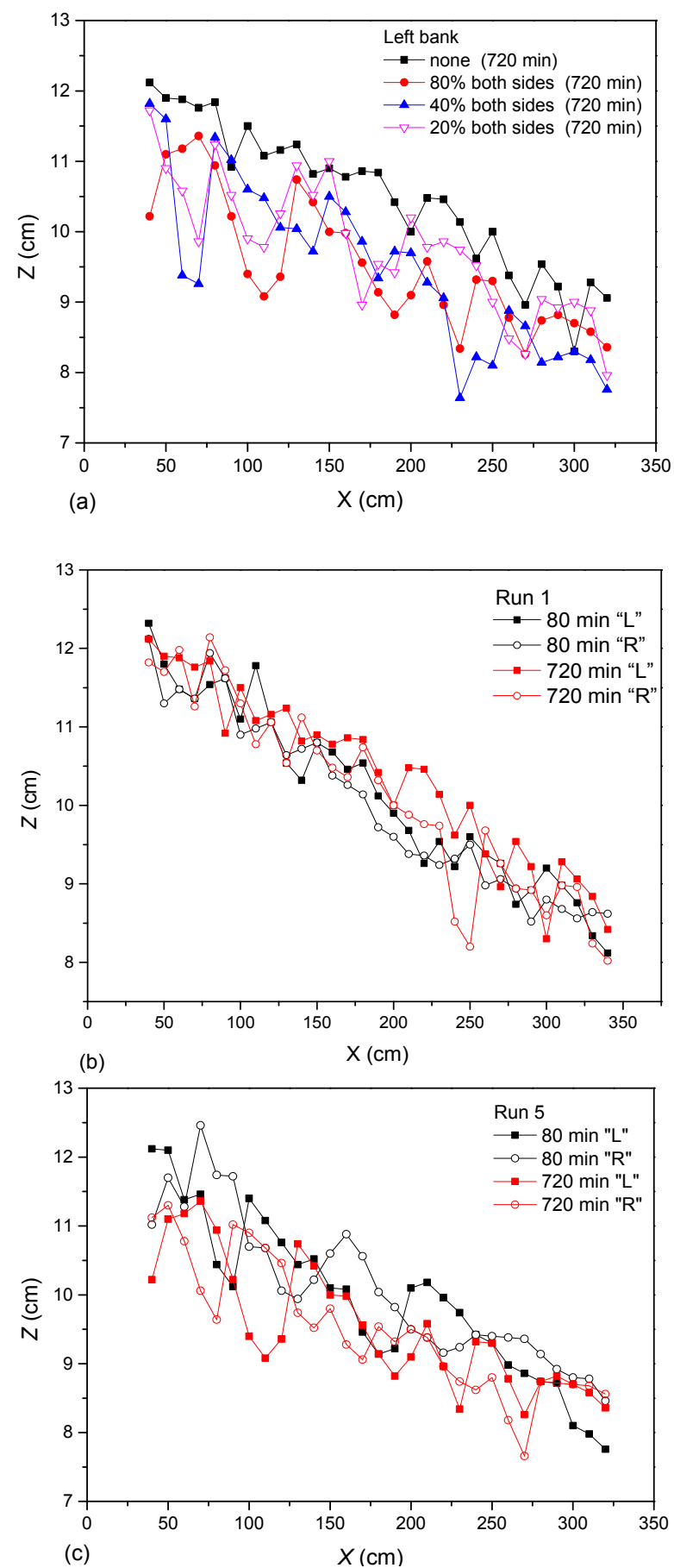

Figure 14. Longitudinal variation of near-bank bed elevation (a) for different riparian vegetation cover, (b) no riparian vegetation coverage in Run 1 and (c) 80\% riparian vegetation coverage in Run 5, where $\mathrm{L}$ represents left bank and $\mathrm{R}$ represents right bank in the figure legend. 

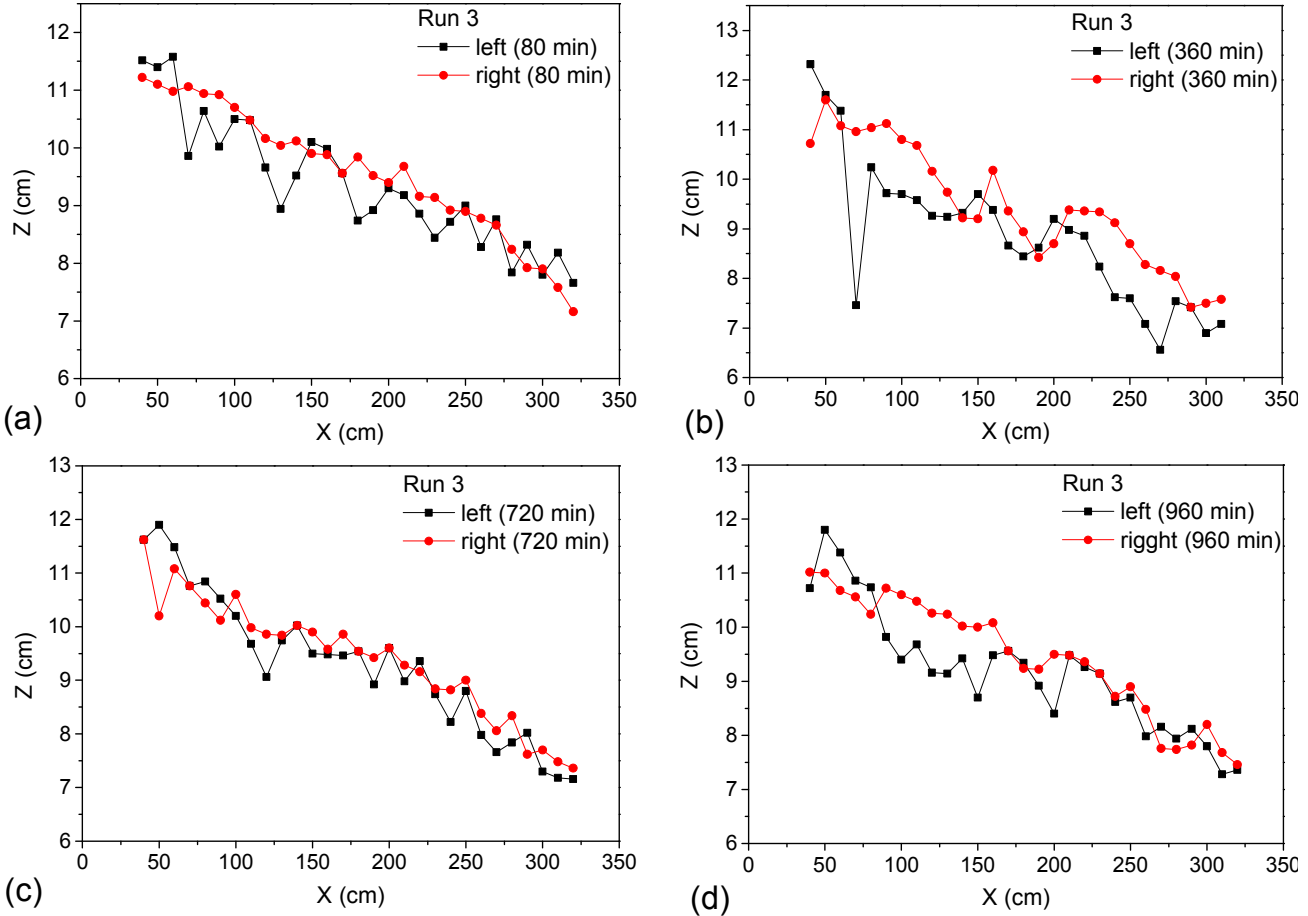

Figure 15. Longitudinal variation of near-bank bed elevation for unilateral riparian vegetation cover and with $80 \%$ vegetation coverage $(\mathbf{a}) \mathrm{t}=80 \mathrm{~min},(\mathbf{b}) \mathrm{t}=360 \mathrm{~min},(\mathbf{c}) \mathrm{t}=720 \mathrm{~min}$ and $(\mathbf{d}) \mathrm{t}=80 \mathrm{~min}$.

\subsection{Stability of Meanders}

The cross-section of the river bed mainly reflected the process of erosion and deposition of the riverbed and also reflected its widening process. Four runs $(1,3,5$ and 6$)$ under different conditions were selected for comparative analysis (Figure 16a-d, respectively). The focused time frame was from $0 \mathrm{~min}$ to the final stable time. We chose the section of the second to fifth as the typical sections to study ignoring the impact of entry and exit, and the corresponding transverse section of $x=1.0 \mathrm{~m}(\mathrm{~S} 2)$, $\mathrm{x}=1.5 \mathrm{~m}(\mathrm{~S} 3), \mathrm{x}=2.0 \mathrm{~m}$ (S4) and $\mathrm{x}=2.5 \mathrm{~m}$ (S5). The cross-section was chosen to approximate the half wavelength of the meandering channel (Run 1), and the spacing was about $0.5 \mathrm{~m}$.

For Run 1, observations showed that the riverbed overall expanded and silted up in the initial state, then along the concave bank, the scour deepened, obviously forming the main channel. The main channel alternatingly swung from the left bank to the right bank, forming a stable meandering channel. For Run 3, unilateral vegetation cover of its riverbanks, the channel was in the stage of adjustment in the initial $80 \mathrm{~min}$, rapidly widening with siltation uplifting, the same as in Run 1 . With the continued evolution of the river channel, unlike Run 1, Run 3 showed an obvious unilateral scour along the vegetation covered side, and the main channel swung to the left. Especially after $x \geq 2.0 \mathrm{~m}$, there was a special phenomenon of one side shoal and the other side a deep trough.

In the period of continuous extension of the river channel, Run 3 showed some unique processes, which were different from the phenomena of many previous river evolution experiments. Compared with the continuous silting up of the riverbed of Run 1, the riverbed of Run 3 showed first aggradation and then degradation. The main reason for this phenomenon was the unilateral perturbation, which led to the asynchrony of the two river bank sides, and the water flow showed constant disturbance. The riverbed was always in the process of constant siltation and erosion. This strong asynchronous perturbation was also shown in the cross-section of the riverbed, showing multi-groups of alternating distributions of secondary deep troughs and shoals. Seen from Figure 16c, although the left bank was constantly deeply scouring, the lateral extension was equal to or less than the right bank, especially evident in the downstream $x \geq 2.0 \mathrm{~m}$. Finally, a secondary channel was formed at $x=2.0 \mathrm{~m}$, with a new first deep trough and multiple secondary deep troughs. At the same time, the initial first deep 
trough was abandoned, and the left bank point bar had become the new river bank of the secondary channel. Vegetation played an obvious role in riparian protection.

For Runs 5 and 6, with bilateral vegetation cover on the riverbanks, after the rapidly widened and siltation uplifted phenomena ( $\mathrm{t}<80 \mathrm{~min}$ ), most of its river channel reaches showed the phenomenon of first brushing deep and then silting up. This showed that the bilateral vegetation cover on the riverbank effectively controlled the continuous deep brushing of the riverbed. Looking at Figure 16d, we found that a continuous alternate shoal along the riverbank finally formed, showing a stable duplex bed forming with less secondary deep troughs. S2, S3 and S4 present the phenomenon of narrowing and deposition on both bank sides. Therefore, the channel with bilateral vegetation cover had a relatively stable bed morphology that could effectively restrain the continuous riverbank erosion process compared to the channel with unilateral vegetation cover. The formed stable width-depth radio was lower than under no or unilateral vegetation cover. Therefore, a narrow and deep channel more easily formed for the channel with bilateral vegetation cover during the flood period.
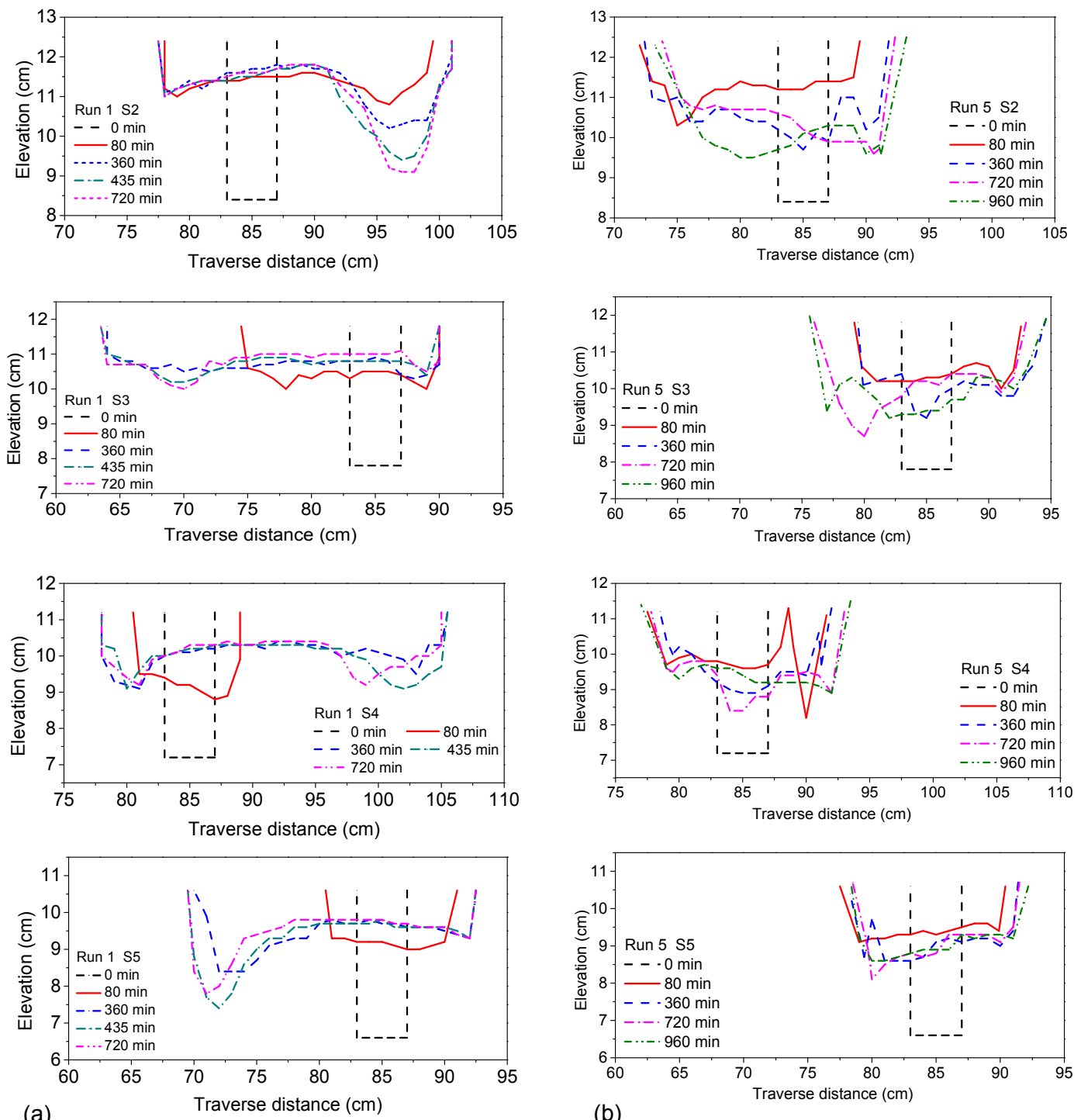

(b)

Figure 16. Cont. 

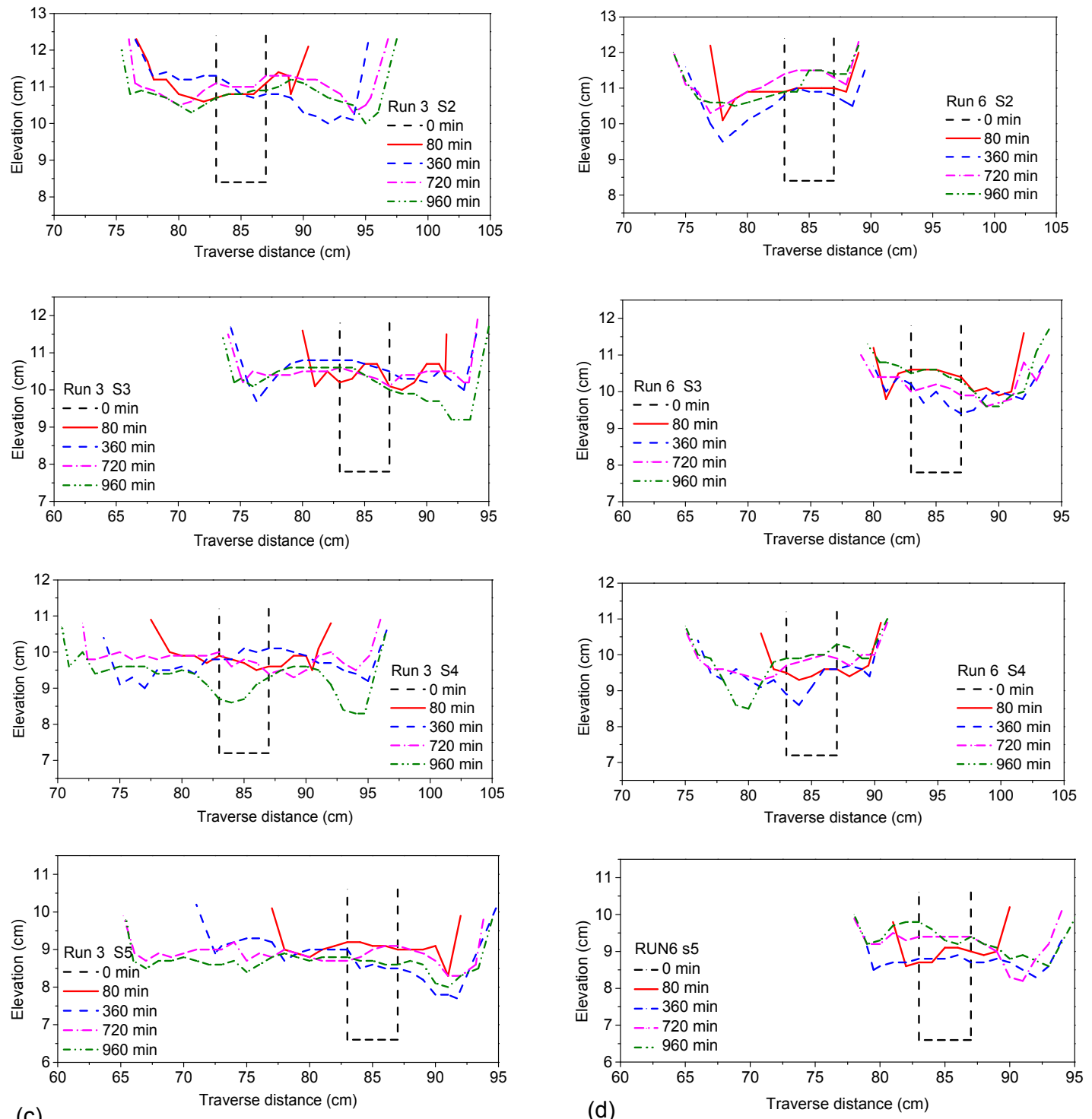

(c)

Figure 16. Evolution of the cross-section during four experimental runs: (a) Run 1, (b) Run 5, (c) Run 3 and (d) Run 6. Flow direction points to the observer.

\subsection{Sediment Transport Rate}

As shown in Figure 17, under the condition of initial excavation and a small-scale straight path, the fluctuation in the channel sediment transport rate decreased with the adjustment of water flow and channel, and finally reached a relatively stable state. In terms of trough measurements, we found that there was a common rule for different vegetation coverage rates: the sediment transport rate of unilateral vegetation cover was greater than that of bilateral vegetation cover at the initial stage, but was lower at the stable stage. In Run 3, due to the strong unilateral disturbance and the instability of flow structure, the sediment transport was strong at the initial stage, and the gradient and amplitude of the sediment transport rate curve were larger than for runs without vegetation. As for Run 6, because of the mutual inhibition between the two sides, the sediment transport rate was smaller than Run 3 and then had an increasing trend at the initial stage. 


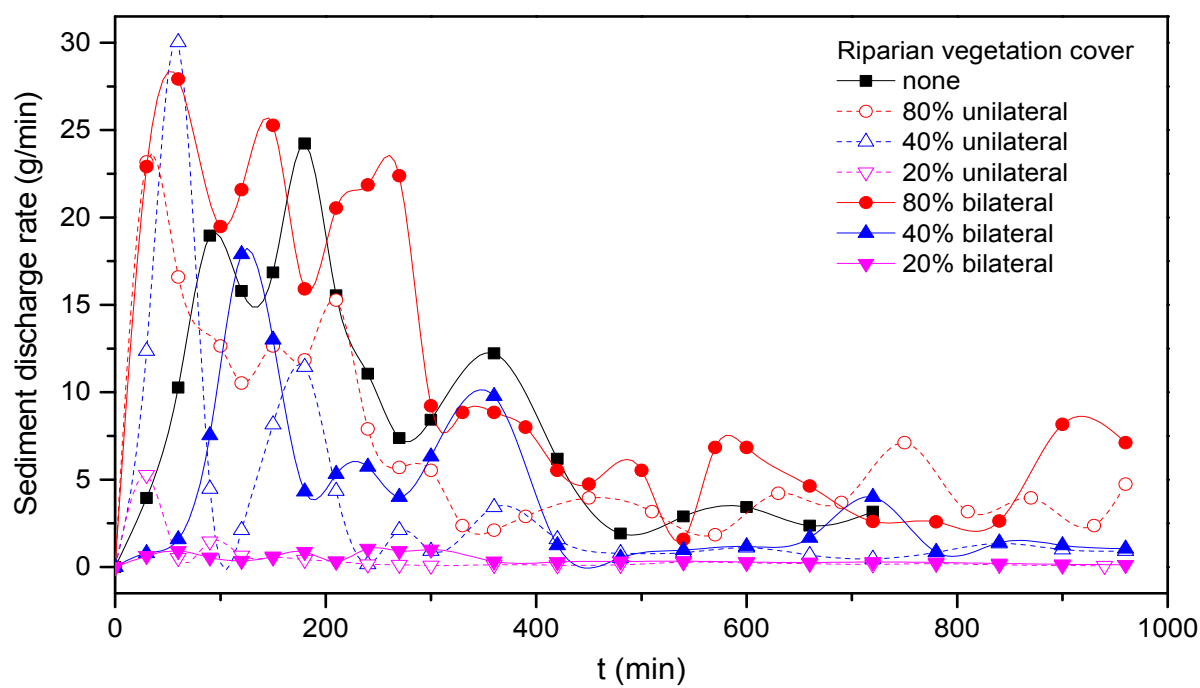

Figure 17. Time history of the sediment transport rate in bends.

For the experimental scale of this small river channel, the maximum allowable dry fine sand passing with the flow was about $1.5 \mathrm{~g} / \mathrm{min}$ for recovering the bedload sediment deficit, whereas the suspended load was derived from bank erosion as the channel progressed [32]. For the seven groups of experiments, the final relatively stable sediment transport rates are shown in Table 5. For $20 \%$ and $40 \%$ vegetation coverage rates under unilateral and bilateral riverbank vegetation coverage, the average sediment transport rates were significantly lower than without vegetation cover. When the flow passed through the vegetation zone, the existence of riparian plants increased the local hydraulic roughness, decreased the flow velocity and increased the sedimentation, and the vegetation zone effectively inhibited the lateral scour of the river channel. However, for the $80 \%$ vegetation coverage rate, the sediment transport rate increased.

Table 5. Statistics of final stable sediment transport rate in different working conditions.

\begin{tabular}{cc}
\hline Run & Stable Sediment Transport Rate $(\mathrm{g} / \mathrm{min})$ \\
\hline 1 & 3.16 \\
2 & 4.74 \\
3 & 0.92 \\
4 & 0.068 \\
5 & 7.11 \\
6 & 1.05 \\
7 & 0.11 \\
\hline
\end{tabular}

The reasons for these findings are as follows. Although the planted riparian vegetation played a role in a flexible bank to a certain extent, when the planting of vegetation was very dense, vegetation revetment became a hard constraint, similar to a riparian vegetation wall. Although riparian vegetation increased riparian intensity to the greatest extent, it increased the disturbance of the river channel. Although the lateral scour was suppressed, the vertical scour of the river channel increased. It can be clearly seen from the cross-section diagram of Run 5 in Section 3.2. At the same time, because of the inhibition of the vegetation on the lateral scour, the width of the channel was relatively small, the main stream flow velocity relatively increased and the sediment carrying capacity of the flow was enhanced. Therefore, the influence of riparian vegetation coverage on river channel sediment transport rate can be positive and negative and has a strong relationship with the density of vegetation. A certain amount of vegetation cover can effectively reduce the sediment transport rate.

From different riparian vegetation coverage rates, we found that sediment transport increased with increasing coverage rate, and good consistency was maintained between unilateral and bilateral 
banks. The influence of the degree of coverage on the sediment transport rate was not a simple linear relationship; the amount of sediment transported corresponding to $20 \%$ vegetation coverage was much lower than that of the $40 \%$ and $80 \%$ vegetation coverage. This is because, under $20 \%$ vegetation coverage, the local disturbance of riparian vegetation to water flow was much smaller than that of the other two conditions, especially in the initial stage of river channel evolution. However, this had a good reinforcement effect on the river bank, reducing the erosion.

\section{Discussion}

To obtain specific knowledge on riparian vegetation and bank and bed stabilization in a scaled experiment, river channel evolution experiments were conducted. These experiments highlight the effect on the evolution characteristics including the hydraulic characteristics of flow, river bank evolution characteristics and the stability of meanders

In flood plains, riparian vegetation is one of the leading factors of river regime change. The braided river, in the absence of vegetation cover, has the tendency to decrease the number of channels compared to when plant vegetation is present. Due to differences in riparian vegetation factors, braided rivers may gradually develop into narrower and deeper meandering rivers under certain riparian vegetation conditions [58]. Vegetation removal could cause greater migration in the downstream versus the cross-stream direction and could therefore result in perhaps a less sinuous channel pattern over time [50].

An indirect effect of root cohesion is that when a bank fails, undermined riparian vegetation often remains attached to the bank edge, with the potential to reduce near-bank flow velocities [50]. This shows that, when the riparian vegetation coverage is large or small, although the local river meander changes obviously, the lateral migration of the whole river channel is still uniform. The Lower Truckee River, Nevada, U.S., has been lined by dense riparian forest during different time intervals (1946-1969, 1981-1991 and 1991-1997), during which a pattern of relatively uniform bank erosion rates along regular meanders was observed [59]. These findings are in good agreement with our experiment. Different riparian vegetation cover results in different bank erosion rates, which is the inevitable result of the interaction between river bank intensity and sediment transport. Micheli [50] also analyzed the river migration of the Sacramento River over 50 years (1949-1997) by remote sensing, and the erosion coefficient of riparian farmland was $80-150 \%$ larger than that of forest cover. Although the effects of riparian vegetation on river channel evolution are only a generalized model experiment and there is no exact similar data available for a model scale, as a qualitative study, the conclusion is similar to the actual situation.

For sand-bed rivers when there is no vegetation, the morpho-texture of streams may strongly relate to different processes and hydrological regimes [60], and the adjustment of river width increased with the increase in flow hydrodynamic intensity. As time continued, the transverse widening rate slowed down, and the main channel presented a wide and shallow dynamic equilibrium state. Riparian vegetation strongly influences the river bank collapse characteristics. Compared to the slump block caused by local instability of a non-vegetation riparian zone, the gradual erosion intensifies with the increase in riparian vegetation coverage. When the river bank was covered with vegetation, the adjustment of river width was inhibited by vegetation, leading to the increase in the main channel's disturbance and the increase in the main river channel velocity. In the experiment with riparian coverage, resistance of vegetation resulted in increased flow velocity and deeper scour, which is important for the meandering channel.

The cohesive force of riparian vegetation showed that when riparian instability occurs, the destruction of riparian vegetation is often attached to riparian margins, which may reduce the flow velocity of the river bank [50]. Therefore, when only one side of vegetation is planted, the flow tends to be concentrated in areas without vegetation. Riparian vegetation seriously inhibited the erosion of the river bank, leading to a high velocity area formed in the corresponding non-vegetation riparian inner-bank, and intensified the erosion of the riverbed and riverbank. With bilateral vegetation cover, 
due to the increase in vegetation zone resistance and the influence of local circulation, the homeopathic scour of flow was reduced, and the main stream on the inner-bank side of the river deflected to the central portion of the channel, further affecting the sediment deposition and the change of riverbed topography. Therefore, the more intensive the riparian vegetation, the stronger the local perturbation of water flow to the riverbed, and the longer the adaptation period of the riverbed to the water flow, the longer the time from the initial straight channel to the formation of stable river channel facies.

The influence of vegetation density on river channel sediment transport reflects the proportion relationship between the effect of riparian vegetation on water disturbance and bank protection. Appropriate riparian vegetation coverage can effectively reduce the sediment transport rate, and the channel can maintain its equilibrium state of erosion and deposition (such as in Runs 4 and 7) during the process of its evolution. In this paper, for the riparian vegetation cover condition, the smaller the coverage rate, the better the effect of controlling the sediment transport. However, when hydrodynamic conditions and vegetation boundary conditions changed (for example, vegetation types and flow conditions change), there may be different results, which need further research and discussion.

In the experiment, we discussed the evolution of a river with a small-scale model, which is a generalization model. Similarity criteria were not considered in the model, and a series of complex conditions, such as riparian vegetation resistance and slope gradient, were also quite different from those of natural rivers. These differences mean the experimental results cannot be directly extended to actual rivers according to a certain scale. However, our findings provide a realistic understanding of a series of complex changes in riparian vegetation resistance, channel widening and dynamic axis migration, which provide an important practical basis for constructing theoretical and mathematical models of natural river evolution under different vegetation conditions. Additionally, this study has practical significance for river evolution and artificial vegetation planting for flood damage mitigation.

These results provide new insights into evaluating the interactions between naturally-colonizing vegetation and the morphodynamics of a newly-cut river channel [15]. For some artificial regional riparian vegetation planning projects aimed at changing the hydrodynamic condition of the river channel boundary, different results in morphology can be rapidly produced. Meanwhile, the response of rivers to interventions will be monitored through implementing pre-and post-project assessments of river revetment projects, particularly on urban water courses [61]. Furthermore, such experiments complement numerical modeling where a host of dynamic properties and settling conditions for plants and for the interactions between plants and flow at various scales must be specified, and therefore require detailed data $[62,63]$.

\section{Conclusions}

By controlling the riparian vegetation coverage, the evolution characteristics of rivers with or without vegetation were observed and the evolution characteristics were analyzed. The main conclusions are as follows:

In the experimental conditions, the flow dynamic axis of the non-vegetated river was close to concave and inclined downstream, and the erosion proceeded along the horizontal and vertical directions, eventually forming a meandering river. For the vegetation coverage on both bank sides, the more intensive the vegetation coverage, the stronger the local disturbance to the river bed. The homeopathic scour of flow was reduced, and the adaptation period between the river bed and the water flow increased. For the vegetation coverage on one bank side, point bars were easily formed and deposited along the vegetation shore, the main stream inclined to the other shore and the river maintained a long-term unstable state regime.

Riparian vegetation coverage increased the main channel disturbance, increasing the local velocity and effectively reducing the lateral migration of river while increasing the vertical migration to the downstream, thus reducing the curvature of the river. The rate of meander migration and the concave disturbance velocity were positively related. The greater the vegetation coverage, the greater the shear force required for river evolution. 
For the initial straight and narrow-deep channel, the widening rate of river banks decreased exponentially with time. The coverage of riparian vegetation slowed the widening rate of the river effectively, but its influence was nonlinear. Under the condition of riparian vegetation in this experiment, the average widening rate of the river bank was ordered as $40 \%>80 \%>20 \%$ for bilateral and unilateral vegetation coverage.

Vegetation coverage strongly influences the bed surface fluctuation, and the fluctuation amplitude of bed elevation increases with vegetation coverage, leading to the increase in the trend of overall scour depth on the near-bank elevation. The fluctuation of the river bed caused by the change in bank scour resistance developed much faster than the plane migration of the river channel. Meanwhile, the sediment transport rate can be effectively reduced under an appropriate riparian vegetation coverage.

Author Contributions: Y.B. and S.Y. conceived the idea and designed the experiments. S.Y. carried out experiments, performed the data processing and wrote the first draft of the manuscript. Y.B. modified the manuscript. H.X. helped with English editing.

Funding: This research was funded by the National Natural Science Foundation of China, grant number 51279124; the National Natural Science Foundation of China, grant number 51803130; the Open Foundation of State Key Laboratory of Hydraulic Engineering Simulation and Safety of Tianjin University of China, grant number, HESS-1715, HESS-1720.

Conflicts of Interest: The authors declare no conflict of interest.

\section{References}

1. Thorne, C.R. Effects of vegetation on riverbank erosion and stability. In Vegetation and Erosion; Thornes, J.B., Ed.; John Wiley: Chichester, UK, 1990; pp. 125-143.

2. Crosato, A.; Saleh, M.S. Numerical study on the effects of floodplain vegetation on river planform style. Earth Surf. Process. Landf. 2010, 36, 711-720.

3. Oorschot, M.V.; Kleinhans, M.; Geerling, G.; Middelkoop, H. Distinct patterns of interaction between vegetation and morphodynamics. Earth Surf. Process. Landf. 2016, 41, 791-808. [CrossRef]

4. Li, Z.W.; Yu, G.A.; Brierley, G.; Wang, Z.Y. Vegetative impacts upon bedload transport capacity and channel stability for differing alluvial planforms in the Yellow River source zone. Hydrol. Earth Syst. Sci. 2016, 20, 3013-3025. [CrossRef]

5. Hickin, E.J. Vegetation and river channel dynamics. Can. Geogr. 1984, 28, 111-126. [CrossRef]

6. Rowntree, K.M.; Dollar, E.S.J. Vegetation controls on channel stability in the Bell River, Eastern Cape, South Africa. Earth Surf. Process. Landf. 1999, 24, 127-134. [CrossRef]

7. Bennett, S.J.; Pirim, T.; Barkdoll, B.D. Using simulated emergent vegetation to alter stream flow direction within a straight experimental channel. Geomorphology 2002, 44, 115-126. [CrossRef]

8. Beeson, C.E.; Doyle, P.F. Comparison of bank erosion at vegetated and non-vegetated channel bends. Water Resour. Bull. 1995, 31, 983-990. [CrossRef]

9. Smith, D.G. Effect of vegetation on lateral migration of Anastomosed channels of a glacier meltwater river. GSA Bull. 1976, 87, 857-860. [CrossRef]

10. Huang, H.Q.; Nanson, G.C. Vegetation and channel variation; a case study of four small streams in Southeastern Australia. Geomorphology 1997, 18, 237-249. [CrossRef]

11. Van de Lageweg, W.I.; Van Dijk, W.M.; Hoendervoogt, R.; Kleinhans, M.G. Effects of riparian vegetation on experimental channel dynamics. In Proceedings of the International Conference on Fluvial Hydraulics River Flow, Braunschweig, Germany, 8-10 September 2010; p. 2.

12. Dan, M.; Wittenberg, L. Scaling the effects of riparian vegetation on cross-sectional characteristics of ephemeral mountain streams-A case study of Nahal Oren, Mt. Carmel, Israel. CATENA 2007, 69, 103-110.

13. Charlton, F.G.; Brown, P.M.; Benson, K.W. The Hydraulic Geometry of Some Gravel Rivers in Britain; Rep. INT-180; Hydraulics Research Station: Wallingford, UK, 1978.

14. Allmendinger, N.E.; Pizzuto, J.E.; Potter, N.; Johnson, T.; Hession, W.C. The influence of riparian vegetation on stream wisth, Eastern Pennsylvania, USA. Geol. Soc. Am. Bull. 2005, 117, 229-243. [CrossRef] 
15. Gurnell, A. Plants as river system engineers. Earth Surf. Process. Landf. 2014, 39, 4-25. [CrossRef]

16. Pollen-Bankhead, N.; Simon, A. Hydrologic and hydraulic effects of riparian root networks on streambank stability: Is mechanical root-reinforcement the whole story? Geomorphology 2010, 116, 353-362. [CrossRef]

17. Luhar, M.; Nepf, H.M. From the blade scale to the reach scale: A characterization of aquatic vegetative drag. Adv. Water Resour. 2013, 51, 305-316. [CrossRef]

18. Perucca, E.; Camporeale, C.; Ridolfi, L. Significance of the riparian vegetation dynamics on meandering river morphodynamics. Water Resour. Res. 2007, 43, W03430. [CrossRef]

19. Vesipa, R.; Camporeale, C.; Ridolfi, L. Noise-driven cooperative dynamics between vegetation and topography in riparian zones. Geophys. Res. Lett. 2015, 42, 8021-8030. [CrossRef]

20. Liu, D.; Diplas, P.; Hodges, C.C.; Fairbanks, J.D. Hydrodynamics of flow through double layer rigid vegetation. Geomorphology 2010, 116, 286-296. [CrossRef]

21. Mcbride, M.; Hession, W.C.; Rizzo, D.M.; Thompson, D.M. The influence of riparian vegetation on near-bank turbulence: A flume experiment. Earth Surf. Process. Landf. 2010, 32, 2019-2037. [CrossRef]

22. Li, K.; Stella, J.C.; Lightbody, A.; Wilcox, A.C. Ecogeomorphic feedbacks and flood loss of riparian tree seedlings in meandering channel experiments. Water Resour. Res. 2014, 50, 9366-9384.

23. Tal, M.; Paola, C. Effects of vegetation on channel morphodynamics: Results and insights from laboratory experiments. Earth Surf. Process. Landf. 2010, 35, 1014-1028. [CrossRef]

24. Tal, M.; Paola, C. Dynamic single-thread channels maintained by the interaction of flow and vegetation. Geology 2007, 35, 1651-1656. [CrossRef]

25. Bennett, S.J. Effects of Emergent Riparian Vegetation on Spatially Averaged and Turbulent Flow within an Experimental Channel. In Riparian Vegetation and Fluvial Geomorphology; American Geophysical Union: Washington, DC, USA, 2004; pp. 29-41.

26. Bennett, S.J.; Wu, W.; Alonso, C.V.; Wang, S.S.Y. Modeling fluvial response to in-stream woody vegetation: Implications for stream corridor restoration. Earth Surf. Process. Landf. 2010, 33, 890-909.

27. Crouzy, B.; Perona, P. Biomass selection by floods and related timescales. Part 2: Stochastic modeling. Adv. Water Resour. 2012, 39, 97-105. [CrossRef]

28. Perona, P.; Molnar, P.; Crouzy, B.; Perccca, E.; Jiang, Z.; Mclelland, S.; Wuthrich, D.; Edmaier, K.; Francis, R.; Camporeale, C.; et al. Biomass selection by floods and related timescales: Part: 1. Experimental observations. Adv. Water Resour. 2012, 39, 85-96. [CrossRef]

29. Perona, P.; Crouzy, B. Resilience of riverbed vegetation to uprooting by flow. Proc. R. Soc. A 2018, 474. [CrossRef]

30. Perignon, M.C.; Tucker, G.E.; Griffin, E.R.; Friedman, J.M. Effects of riparian vegetation on topographic change during a large flood event, Rio Puerco, New Mexico, USA. J. Geophys. Res. Earth Surf. 2013, 118, 1193-1209. [CrossRef]

31. Schumm, S.A.; Khan, H.R. Experimental study of channel patterns. GSA Bull. 1972, 83, 1755-1770. [CrossRef]

32. Jin, D.; Schumm, S.A. A new technique for modeling river morphology. In Proceedings of the First International Geomorphology Conference, Manchester, UK, 15-21 September 1985; Richards, K.S., Ed.; Wiley: Chichester, UK, 1986; pp. 681-690.

33. Peakall, J.; Ashworth, P.J.; Best, J.L. Meander-bend evolution alluvial architecture, and the role $\mathrm{f}$ cohesion in sinuous rive channels: A flume study. J. Sediment. Res. 2007, 77, 197-212. [CrossRef]

34. Van Dijk, W.M.; Van de Lageweg, W.I.; Kleinhans, M.G. Formation of a cohesive floodplain in a dynamic experimental meandering river. Earth Surf. Process. Landf. 2013, 38, 1550-1565. [CrossRef]

35. Schumm, S.A. Geomorphic thresholds and the complex response of drainage system. In Fluvial Geomorphology; Publication of Geomorphology, State University of New York: Binghamton, NY, USA, 1973; pp. 299-310.

36. Bai, Y.C.; Xu, D. Study on particle tracking velocimetry in complex surface flow field. In Proceedings of the 20th National Conference on Hydrodynamics, Taiyuan, China, 23-25 Auguest 2007; Ocean Press: Beijing, China, 2007; pp. 430-438. (In Chinese)

37. Song, X.L.; Bai, Y.C.; Ying, C. A three-dimensional topographic survey based on two-dimensional image information. J. Zhejiang Univ. Sci. A 2014, 15, 68-82. [CrossRef] 
38. Dulal, K.P.; Shimizu, Y. Experimental simulation of meandering in clay mixed sediments. J. Hydro-Environ. Res. 2010, 4, 329-343. [CrossRef]

39. Malverti, L.; Lajeunesse, E.; Metivier, F. Small is beautiful: Upscaling from microscale laminar to natural turbulent rivers. J. Geophys. Res. Earth Surf. 2008, 113, F04004. [CrossRef]

40. Edmaier, K.; Burlando, P.; Perona, P. Mechanisms of vegetation uprooting by flow in alluvial non-cohesive sediment. Hydrol. Earth Syst. Sci. 2011, 15, 1615-1627. [CrossRef]

41. Edmaier, K.; Crouzy, B.; Perona, P. Flow-induced uprooting of young vegetation on river bedforms. Acta Pet. Sin. 2014, 27, 952-958.

42. Bywater-Reyes, S.; Wilcox, A.C.; Stella, J.C.; Lightbody, A.F. Flow and scour constraints on uprooting of pioneer woody seedlings. Water Resour. Res. 2015, 51, 9190-9206. [CrossRef]

43. Gran, K.; Paola, C. Riparian vegetation controls on braided stream dynamics. Water Resour. Res. 2001, 37, 3275-3283.

44. Braudrick, C.A.; Dietrich, W.E.; Leverich, G.T.; Sklar, L.S. Experimental evidence for the conditions necessary to sustain meandering in coarse-bedded rivers. Proc. Natl. Acad. Sci. USA 2009, 106, 16936-16941. [CrossRef] [PubMed]

45. Pollen, N.; Simon, A. Geotechnical Implications for the use of Alfalfa in Experimental Studies of Alluvial-Channel Morphology and Planform. In Proceedings of the AGU Fall Meeting, San Francisco, CA, USA, 11-15 December 2006.

46. Parthenaides, E. Erosion and deposition of cohesive soils. J. Hydraul. Div. 1965, 91, 105-139.

47. Thorne, C.R. Process and mechanisms of river bank erosion. In Gravel-Bed Rivers; Hey, R.D., Bathurst, J.C., Thorne, C.R., Eds.; Wiley: Chichester, UK, 1982; pp. 227-259.

48. Ikeda, S.; Parker, G.; Sawai, K. Bend theory of river meanders, part 1: Linear development. J. Fluid Mech. 1981, 112, 363-377. [CrossRef]

49. Larsen, E.W. Mechanics and Modeling of River Meander Migration. Ph.D. Thesis, Department of Civil Engineering, University of California, Berkeley, CA, USA, 1995.

50. Micheli, E.R.; Kirchner, J.W.; Larsen, E.W. Quantifying the effect of riparian forest versus agricultural vegetation on river meander migration rates, central Sacramento River, California, USA. River Res. Appl. 2004, 20, 537-548. [CrossRef]

51. Dietrich, W.E.; Smith, J.D. Bed load transport in a river meander. Water Resour. Res. 1984, 20, 1355-1380. [CrossRef]

52. Hasegawa, K. Universal bank erosion coefficient for meandering rivers. J. Hydraul. Eng. 1989, 115, 744-765. [CrossRef]

53. Johannesson, H.; Parker, G. Linear theory of river meanders. In River Meandering; Ikeda, S., Syunsuke, T., Parker, G., Eds.; American Geophysical Union: Washington, DC, USA, 1989; pp. 181-213.

54. Pizzuto, J.; Meckelnberg, T. Evaluation of a linear bank erosion equation. Water Resour. Res. 1989, 25, 1005-1013. [CrossRef]

55. Xu, D.; Bai, Y.C.; Tan, Y. Experimental study on the formation and development of alluvial river meanders with non-cohesive sand bedded natural river model. J. Hydraul. Eng. 2011, 42, 918-927. (In Chinese)

56. Wang, P.Y.; Wen, C. Experimental study on migration process in alluvial curved rivers. J. Hydrodyn. Ser. A 2001, 16, 312-318. (In Chinese)

57. Zhang, J.Y.; Chen, L.; Wang, Z.G.; Zhang, C.Y. Investigation on valid duration of natural river model. J. Hydraul. Eng. 2006, 37, 365-370. (In Chinese)

58. Jang, C.L.; Shimizu, Y. Vegetation effects on the morphological behavior of alluvial channels. J. Hydraul. Res. 2007, 45, 763-772. [CrossRef]

59. Micheli, E.R. Quantifying the Effects of Riparian Vegetation on River Meander Migration. Ph.D. Thesis, Energy and Resources Group, University of California, Berkeley, CA, USA, 2000.

60. Storz-Peretz, Y.; Laronne, J.B.; Surian, N.; Lucia, A. Flow recession as a driver of the morpho-texture of braided streams. Earth Surf. Process. Landf. 2016, 41, 754-770. [CrossRef]

61. Gurnell, A.; Petts, G. Trees as riparian engineers: The Tagliamento river, Italy. Earth Surf. Process. Landf. 2010, 31, 1558-1574. [CrossRef] 
62. Schnauder, I.; Moggridge, H.L. Vegetation and hydraulic-morphological interactions at the individual plant, patch and channel scale. Aquat. Sci. 2009, 71, 318-330. [CrossRef]

63. Camporeale, C.; Perucca, E.; Ridolfi, L.; Gurnell, A.M. Modeling the interactions between river morphodynamics and riparian vegetation. Rev. Geophys. 2013, 51, 379-414. [CrossRef] 